Международная Объединенная Академия Наук

\title{
Научный диалог: Молодой ученый
}

Сборник научных трудов

по материалам

XXI международной научной конференции

22 ноября 2018 г.

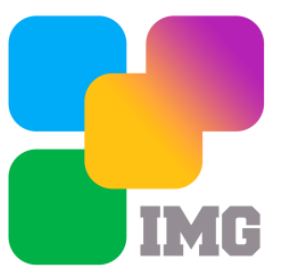

Санкт-Петербург 2018 
УДК 001.1

ББК 60

Научный диалог: Молодой ученый. Сборник научных трудов, по материалам XXI международной научно-практической конференции 22 ноября 2018 г. Изд. ЦНК МОАН, 2018. - 40с.

\section{SPLN 001-000001-0358-YS \\ DOI 10.18411/spc-22-11-2018 \\ IDSP spub-22-11-2018}

В сборнике научных трудов собраны материалы из различных областей научных знаний. В данном издании приведены все материалы, которые были присланы на XXI международную научно-практическую конференцию Научный диалог: Молодой ученый

Сборник предназначен для научных работников, преподавателей, аспирантов и студентов.

Все материалы, размещенные в сборнике, опубликованы в авторском варианте. Редакция не вносила коррективы в научные статьи. Ответственность за информацию, размещенную в материалах на всеобщее обозрение, несут их авторы.

Информация об опубликованных статьях будет передана в систему Российского индекса научного цитирования (РИНЦ) и наукометрическую базу SPINDEX

Электронная версия сборника доступна на сайте ЦНК MOAН. Сайт центра: conf.sciencepublic.ru

УДК 001.1

ББК 60 


\section{Содержание}

РАЗДЕЛ І. ИНФОРМАЦИОННЫЕ ТЕХНОЛОГИИ 4

Иванова Е.П. Алгоритмизация моделируемой археологической геоинформационной системы

РАЗДЕЛ ІІ. ТЕХНИЧЕСКИЕ НАУКИ 7

Ефимов В.В., Халиулин Д.В., Халиулина Л.Э. Осложнения очистки промысловой продукции сеноманской залежи Ямбургского месторождения на завершающей стадии разработки.

РАЗДЕЛ ІІІ. ЮРИСПРУДЕНЦИЯ 14

Алехина А.А. Социально-правовая природа суда присяжных 14

Лисицына Е.Н. Правовая природа прецедентного нормотворчества европейского суда по правам человека

Переверзева А.Е. Деформация личности адвоката и юридические последствия проявления данного феномена.

Тузкова А.А. Проблемы судопроизводства по делам, связанным с возмещением вреда здоровью в лечебных учреждениях

РАЗДЕЛ IV. ПЕДАГОГИКА

Шатская О.В., Войтик И.А. Структурирование исполнительской (координационномышечной) специфики дисциплин в системе дополнительного образования на примере академического вокала

РАЗДЕЛ V. ПСИХОЛОГИЯ .28

Кадырбаева Н.P., Дмитриева Л.Г. Межличностные отношения в воинском коллективе.

РАЗДЕЛ VI. МЕНЕДЖМЕНТ

Черноусова T.A. Механизм управления финансово-хозяйственной деятельностью предприятия .....

РАЗДЕЛ VІІ. СЕЛЬСКОЕ ХОЗЯЙСТВО

Третьякова О.Л., Зубаиров Р.С., Пирожков Д.А. Оценка потенциала продуктивности материнской свинки. 


\title{
РАЗДЕЛ І. ИНФОРМАЦИОННЫЕ ТЕХНОЛОГИИ
}

\author{
Иванова Е.П. \\ Алгоритмизация моделируемой археологической геоинформационной системы \\ ФГБОУ ВО «Оренбургский государственный университет» \\ (Россия, Оренбург)
}

doi:10.18411/spc-22-11-2018-01

idsp: spub-22-11-2018-01

\section{Аннотация}

В настоящей работе будет обсуждаться метод статистических гипотез, который применяется в археологических геоинформационных системах. Кроме того, будет представлена методика использования полученной модели геоинформационной системы. В заключении показан алгоритм реализации метода статистических гипотез.

Ключевые слова: геоинформационная система, археология, метод статистических гипотез, объекты археологического наследия.

\section{Введение}

Геоинформационные системы (ГИС) в археологической науке стали применяться с конца XX века, когда исследовать большой комплекс объектов археологического наследия, применяя традиционные методы, стало затруднительно.

ГИС фиксирует расположение объектов в пространстве, а также их предположительное местонахождение на территориях, которые плохо исследованы или не исследованы вовсе.

Целью нашей работы является: автоматизация информационных процессов археологической геоинформационной системы.

Наша задача состоит в проверке достоверного наличия, на определенной территории, преобладающей культуры, используя археологические объекты.

\section{Аппарат моделирования и алгоритм реализации математического метода}

Достижение поставленной цели будет осуществляться с помощью метода статистических гипотез, используя который можно проверить предположение относительно свойств определенной совокупности: противоречит ли нулевая гипотеза $\left(H_{0}\right)$ полученным данным для выборки [1].

В качестве исходных параметров (Таблица 1) были выбраны следующие показатели:

- исло найденных объектов археологического наследия (ед.);

- $\quad$ достоверность местонахождения объектов (\%);

- датировка данных объектов (IV-V вв. до н.э.);

- точность относительно принадлежности к указанной культуре (\%).

Предполагается гипотеза $H_{0}$ :

Филипповский курганный могильник принадлежит Савромато-сарматской культуре VI-V вв. до н.э. [2]. 
Таблица 1

Параметры археологических объектов

\begin{tabular}{|c|c|c|c|c|c|}
\hline № & Наименование объекта & $\begin{array}{l}\text { Число } \\
\text { найденных } \\
\text { объектов (ед.) }\end{array}$ & $\begin{array}{l}\text { Достоверное } \\
\text { местонахожде } \\
\text { ние (\%) }\end{array}$ & $\begin{array}{l}\text { Принадлежность } \\
\text { к культуре (\%) }\end{array}$ & $\begin{array}{l}\text { Датировка } \\
\text { (век до н.э.) }\end{array}$ \\
\hline 1 & Золотые украшения & 41 & 76 & 91 & IV \\
\hline 2 & Украшения из серебра & 31 & 54 & 83 & IV \\
\hline 3 & $\begin{array}{l}\text { Украшения из слоновой } \\
\text { кости }\end{array}$ & 25 & 38 & 73 & V \\
\hline 4 & Украшения из жемчуга & 12 & 65 & 74 & V \\
\hline 5 & $\begin{array}{l}\text { Золотая и серебряная } \\
\text { посуда }\end{array}$ & 6 & 88 & 82 & V \\
\hline 6 & Зеркала & 9 & 89 & 89 & V \\
\hline 7 & Глиняная посуда & 15 & 55 & 85 & V \\
\hline 8 & Бронзовые котлы & 7 & 61 & 74 & V \\
\hline 9 & $\begin{array}{l}\text { Двулезвийные мечи и } \\
\text { кинжалы }\end{array}$ & 9 & 36 & 87 & IV \\
\hline 10 & $\begin{array}{l}\text { Бронзовые навершия } \\
\text { (голова верблюда) }\end{array}$ & 3 & 70 & 99 & V \\
\hline 11 & Лук со стрелами & 30 & 67 & 96 & V \\
\hline \multirow[t]{2}{*}{12} & Защитное вооружение & 10 & 54 & 93 & $\mathrm{~V}$ \\
\hline & Среднее значение & 16,5 & 62,75 & 85,5 & 4,75 \\
\hline
\end{tabular}

1. Для того чтобы проверить многомерную гипотезу применяется Т-критерий Хотеллинга, для её использования следует вначале рассчитать ковариационную матрицу:

$$
\Sigma=\frac{1}{n-1}\left(\hat{X}^{T} \hat{X}\right)=\left(\begin{array}{cccc}
142.727 & -21.773 & 5.818 & -2.864 \\
-21.773 & 283.841 & 40.227 & 2.023 \\
5.818 & 40.227 & 75.727 & -0.409 \\
-2.864 & 2.023 & -0.409 & 0.205
\end{array}\right)
$$

2. Далее рассчитаем обратную ковариационную матрицу:

$$
\sum^{-1}=\frac{1}{\left|\sum\right|} a_{i j} \sum=\left(\begin{array}{cccc}
9.306 \times 10^{-3} & -2.542 \times 10^{-4} & 1.389 \times 10^{-4} & 0.133 \\
-2.542 \times 10^{-4} & 4.214 \times 10^{-3} & -2.49 \times 10^{-3} & -0.05 \\
1.389 \times 10^{-4} & -2.49 \times 10^{-3} & 0.015 & 0.056 \\
0.133 & -0.05 & 0.056 & 7.361
\end{array}\right)
$$

3. Следующим действием мы получим Т-критерий Хотеллинга:

$$
T_{p}^{2}=n(\bar{X}-\mu)^{T} \Sigma^{-1}(\bar{X}-\mu)=33.925
$$

4. Рассчитаем критическое значение:

$$
T_{\alpha, m, n-m}^{2}=\frac{m(n-1)}{n-m} F_{\alpha, m, n-m=35.134}
$$

5. После сравним расчетное и критическое значение:

$$
33.926<35.134
$$

$$
\text { Многомерная гипотеза подтверждается при } \quad T_{p}^{2}<T_{\kappa p(\alpha, \mathrm{m}, \mathrm{n}-\mathrm{m}),}^{2}
$$

следовательно, нулевая гипотеза о равенстве векторов средних значений принимается, 
т.е. Филипповский курганный могильник принадлежит Савромато-сарматской культуре VI-V вв. до н.э.

\section{Заключение}

В наше время многие задачи, которые стоят перед археологической наукой, можно решить, используя геоинформационные системы. Для решения вопросов обработки и анализа информации выбран метод научного исследования проверки статистических гипотез.

$$
* * *
$$

1. Гмурман В.Е. Теория вероятностей и математическая статистика / В.Е. Гмурман. - М.: Юрайт, 2016. -479 c.

2. Пшеничнюк А.Х. Филипповка: Некрополь кочевой знати IV века до н.э. на Южном Урале/ А.X. Пшеничнюк. - Уфа: ИИЯЛ УНЦ РАН, 2012. - 287 с. 


\section{РАЗДЕЛ ІІ. ТЕХНИЧЕСКИЕ НАУКИ}

\section{Ефимов В.В., Халиулин Д.В., Халиулина Л.Э. Осложнения очистки промысловой продукции сеноманской залежи Ямбургского месторождения на завершающей стадии разработки}

ООО «Газпром добыча Ямбург» (Россия, Новый Уренгой)

doi:10.18411/spc-22-11-2018-02

idsp: spub-22-11-2018-02

Одно из крупнейших по запасам газа месторождений Западной Сибири, Ямбургское нефтегазоконденсатное месторождение вступило в заключительную стадию разработки. Эксплуатация сеноманской продуктивной залежи, к которой приурочены основные запасы газа Ямбургского месторождения, на завершающем этапе разработки «сопровождается» проявлением целого ряда технологических осложнений:

- уменьшением дебита эксплуатационных скважин;

- значительными масштабами обводнения продуктивной залежи и, как следствие, активным разрушением призабойной зоны пласта (далее ПЗП);

— высоким содержанием в добываемой продукции пластовой жидкости, конденсационной воды и твердых частиц примеси;

- скоплением на забое обводняющихся скважин и в пониженных местах трассы низкопроизводительных газопроводов-шлейфов больших объемов жидкости и др.

Проявление негативных факторов в сочетании с суровыми климатическими условиями Крайнего Севера способствуют снижению эффективности добычи газа через эксплуатационные скважины и пропускной способности промысловой газотранспортной сети, оказывая при этом существенное влияние на эффективность функционирования газопромыслового оборудования и, в первую очередь, входных сепараторов.

Большой практический интерес, особенно на завершающем этапе разработки месторождения, представляют собой вопросы обеспечения эффективной очистки скважинной продукции. Истощение газоносной залежи сопровождается интенсивным обводнением продуктивных пластов, разрушением ПЗП и заметным выносом из эксплуатационных скважин высокоминерализованной пластовой воды и твердых частиц примеси - породы, оксидов железа, остатков бурового раствора и пр. Процесс отделения из добываемой продукции капельной жидкости и твердых частиц называется сепарацией и является обязательным и очень важным элементом технологического процесса промысловой подготовки газа, так как от эффективной работы сепарационного оборудования зависит надежная, безаварийная работа газопромыслового комплекса и качество товарной продукции.

Особенностью коллекторной схемы подвода газожидкостной смеси к входным сепараторам является неравномерная их нагрузка по жидкости, поэтому основным критерием эффективного функционирования сепарационного оборудования, принятым в ООО «Газпром добыча Ямбург», является количество уносимой из сепараторов 
капельной жидкости на единицу объема отсепарированного газа. Чем ниже значение этого параметра, тем эффективнее функционирует сепарационное оборудование.

Результатом неудовлетворительной работы промыслового сепарационного оборудования является высокая концентрация в очищенном во входных сепараторах «сыром» газе твердых частиц и содержащей растворы солей и нежелательных химических реагентов интенсификации процесса добычи капельной жидкости, поступление которых в технологические системы промысловой подготовки негативно воздействует на их работу.

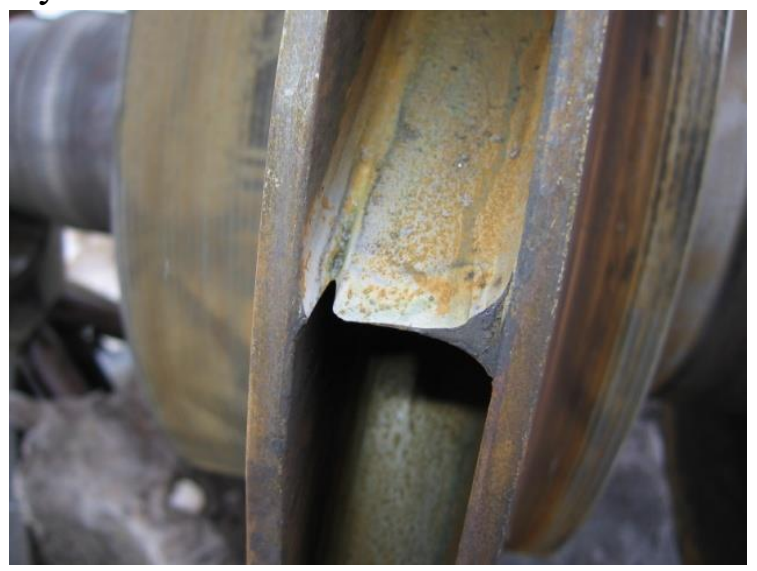

Рисунок 1. Газо-абразивный износ лопаток рабочего колеса ротора центробежного нагнетателя.

Так, поступление в нагнетатели газоперекачивающего агрегата (далее - ГПА) с «сырым» газом твердых частиц и высокоминерализованной капельной жидкости становится причиной газо-абразивного износа рабочих лопаток роторов компрессоров («подрезы» на лопатках ротора - рисунок 1), вызывая образование на лопатках спрямляющих аппаратов и рабочих колес твердых отложений (рисунок 2 а, б, в), и накопление в корпусе сменной проточной части (далее - СПЧ) компрессора жидкости (рисунок 2 г). «Зарастанию» отложениями минеральных солей подвержены, главным образом, те ступени проточной части, в которых с повышением температуры в процессе сжатия происходит испарение содержащейся в «сыром» газе высокоминерализованной капельной влаги. Уменьшение площади рабочих сечений и искажение обтекаемых газом рабочих поверхностей образующимися на элементах проточных частей компрессоров твердыми отложениями приводит к снижению эффективности процесса компримирования. Результатом неравномерного распределения твердых отложений солей на поверхности рабочих колес роторов, в том числе и из-за воздействия при нахождении ГПА в резерве присутствующей в корпусе СПЧ жидкости (рисунок 2 г), является разбалансировка ротора компрессора и необходимость проведения внеплановых дорогостоящих ремонтно-профилактических работ ГПА.

Поступление в систему абсорбционной осушки с потоком «сырого» газа больших объемов воды как в паровой фазе, так и в капельном состоянии, вызывая разбавление растворов гликоля, сопровождается значительным ростом энергетических затрат на регенерацию абсорбента и снижением депрессии по точке росы, что негативно отражается на технико-экономических показателях процесса промысловой подготовки газа. Кроме этого, поступающие в систему абсорбционной осушки растворенные в капельной жидкости минеральные соли и химические реагенты способствуют интенсивному насыщению раствора гликоля минеральными солями, снижению осушающей способности абсорбента и осаждению солей на поверхности 
оборудования и трубопроводов, ухудшая при этом термодинамические показатели функционирования установки осушки, и в первую очередь блока регенерации.

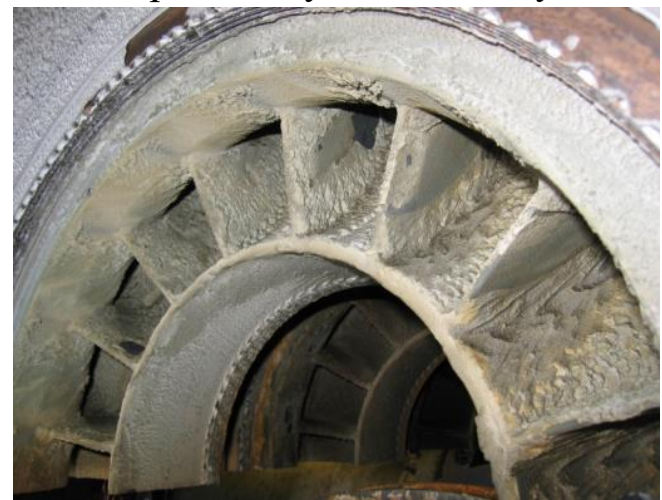

a)

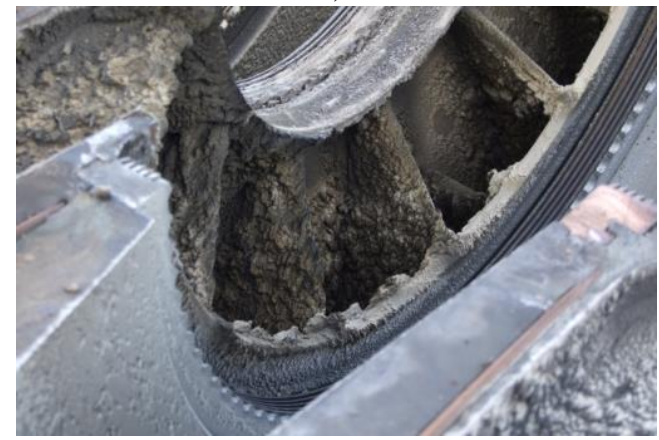

в)

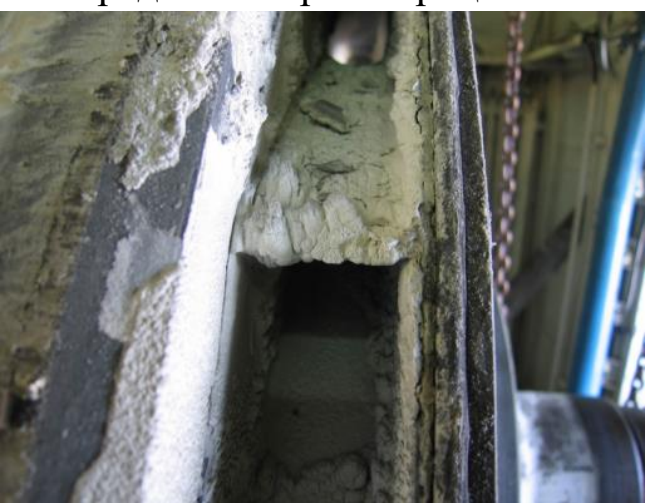

б)

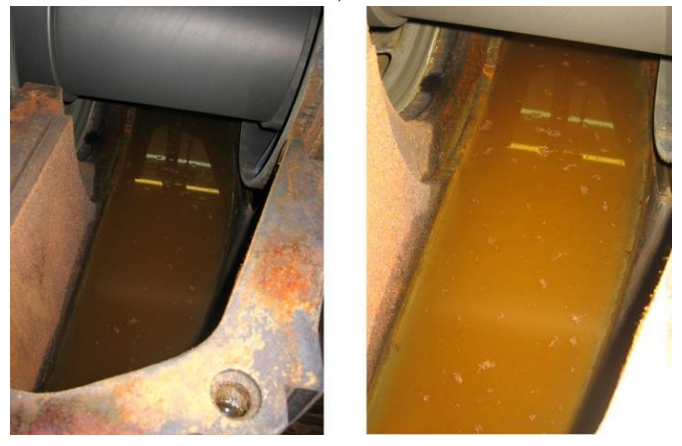

2)

Рисунок 2.«Зарастание» элементов проточных частей центробежных нагнетателей твердыми отложениями (а, б, в) и накопление жидкости в корпусе СПЧ (2).

Промысловые наблюдения за процессом стравливания газа из коллекторов транспортирования неочищенной газожидкостной смеси (при продувках импульсных линий манометров, при опорожнении емкостей-пробкоуловителей через свечу), указывают на дисперсный характер течения потока в трубах, так как присутствующая в отводимом в атмосферу потоке газовой фазы жидкость представляет собой распыленный аэрозоль, что вызывает осложнения при работе приборов контроля давления в газопроводах, вследствие образования в импульсных линиях сплошных гидратных пробок.

Таким образом, присутствие в потоке сепарируемой среды тонкодисперсной капельной жидкости в сочетании с многократной перегрузкой относительно расчетной производительности сепараторов по газу значительно снижает эффективность процесса промысловой очистки газа в сепарационном оборудовании, в составе которого не предусмотрены коалесцирующие секции.

Необходимо также отметить, что дисперсная структура течения потока во входном коллекторе установки очистки газа существенно осложняет работу установленных на тупиковых участках ветвей коллектора емкостей-пробкоуловителей, делая их функционирование неэффективным. Более того, открытые на проток «уравнительные» линии открывают для газожидкостной смеси с высоким содержанием капельной влаги и твердых частиц беспрепятственное поступление на вход компрессоров дожимной компрессорной станции (далее - ДКС), минуя газожидкостные сепараторы. Кроме того, повышение уровня жидкости в емкостяхпробкоуловителях иногда все же наблюдается, и происходит это в моменты поступления на установки комплексной подготовки газа (далее - УКПГ) из 
промысловой газосборной сети больших объемов жидкости, что сопровождается колебаниями давления во входном коллекторе установки очистки газа с весьма высокой амплитудой. Поступление из промысловой газотранспортной сети во входной коллектор большого объема жидкости сопровождается резким снижением в газожидкостном потоке газосодержания [8], [10], вследствие чего образующиеся на поверхности раздела газовой и жидкостной фаз волны, достигая верхней образующей трубы, создают в трубопроводе сплошные жидкостные пробки, часть которых и «скатывается» в емкости-пробкоуловители. Процесс проталкивания через коллектор жидкостных пробок сопровождается сначала «проседанием», а затем резким «броском» давления на входе в сепараторы, что негативно отражается на газодинамической устойчивости компрессоров ДКС и становится причиной уноса жидкости из сепараторов, вследствие возникновения в жидкости эффекта «отрицательного» давления [9].

Как уже отмечалось, завершающая стадия разработки Ямбургского месторождения «сопровождается» снижением давлений на устье, уменьшением производительности и сокращением количества эксплуатационных скважин, работающих в один газопровод-шлейф, способствуя, тем самым, снижению производительности шлейфов и скорости течения транспортируемой газожидкостной смеси, что существенно влияет на формирование структуры двухфазного потока в сопряженных участках (горизонтальном, восходящем и т.п.) профильной трассы газопроводов. Кроме фактора скорости, немаловажную роль в формировании структуры газожидкостного потока играют также количественные соотношения и физические свойства газовой и жидкостной фаз, зависящие, в свою очередь, от давления и температуры на устье скважин, влагосодержания газа в пластовых условиях, степени обводнения продуктивной залежи, количества выносимой из эксплуатационных скважин пластовой жидкости, геометрических размеров газопроводов-шлейфов и др. Особенностью транспортирования газожидкостной смеси по газопроводам-шлейфам в суровых климатических условиях Крайнего Севера является влияние на структуру потока протяженности газопроводов-шлейфов, наличия и состояния теплоизоляции, что во многом определяет изменения термобарических условий в шлейфах под воздействием низких температур окружающей среды.

При некотором «сбалансированном» уровне нагрузки УКПГ в пониженных местах профильной трассы так называемых «слабых» (низкопроизводительных) шлейфов в промысловой газосборной сети происходит скопление жидкости, образуя жидкостные пробки больших объемов. Любые изменения установившегося режима, которые могут быть вызваны целым рядом факторов, таких как: повышение производительности промысловой ДКС при пуске ГПА; закачка в «слабые» шлейфы ингибитора гидратообразования; пуск в работу из резерва или после ремонта эксплуатационных скважин и др., становятся причиной резкого роста местных скоростей потока, интенсифицируя процесс «смены» структуры течения в восходящих участках с «эмульсионной» на «пробковую» или «кольцевую», в зависимости от скорости потока. При этом накопленные в «ловушках» «запасы» жидкости, поступая за короткий период времени на УКПГ, во входные сепараторы, вызывают так называемое «захлебывание» сепарационного оборудования. В момент прохождения жидкостных пробок, объем которых может достигать иногда 50м3, промысловое сепарационное оборудование испытывает значительные перегрузки по жидкости. Ни суммарный объем кубовой части всех сепараторов и емкостей-пробкоуловителей, ни 
производительность (пропускная способность) системы автоматического поддержания в них уровня жидкости не в состоянии за короткий промежуток времени отделить из газожидкостного потока и вывести из сепараторов объемы жидкости, часто в несколько раз превышающие суммарный объем оборудования. Результатом периодических «жидкостных интервенций» из промысловой газотранспортной сети являются уносы из сепараторов значительных объемов жидкости, поступление которых в последующее технологическое оборудование в течение длительного времени нарушает режим его работы.

Для решения проблемы «залповых» поступлений на УКПГ из промысловой газотранспортной сети больших объемов жидкости проектом ПАО "ЮЖНИИГИПРОГАЗ" (далее - институт) предусмотрена предварительная очистка газожидкостной смеси в проточной емкости-пробкоуловителе большого объема (диаметра). Однако авторы настоящей статьи категорически возражают против проектного решения института по использованию пустотелого аппарата для гравитационного осаждения жидкостной фазы по следующему ряду причин. В соответствии с опытом академической науки в области сепарационного оборудования [4], [12], [14] осаждение содержащихся в газожидкостной смеси при ярко выраженной дисперсной структуре потока мелкодисперсных частиц (расчетное значение средневзвешенного диаметра капель 80 мкм) при высокой скорости в аппарате $(1,2 \ldots 1,3 \mathrm{~m} / \mathrm{c})$ без применения коалесцирующих внутренних устройств неэффективно. Примером неэффективной работы гравитационных аппаратов в промысловых условиях являются емкости-пробкоуловители, установленные на тупиковых участках ветвей входного коллектора установки очистки газа. Работа пустотелого аппарата малоэффективна и в процессе залпового выброса из промысловой газосборной сети движущихся с большой скоростью (порядка 25...30 м/с) жидкостных пробок [12]. Вследствие интенсивного вихре- и волнообразования на поверхности раздела фаз «газ жидкость» большая часть жидкой фазы будет уноситься из аппарата в газоотводящий патрубок, в отличие от функционирования емкостей-пробкоуловителей, «скатывание» жидкостных «пачек» в которые происходит за счет образования пробок во входном коллекторе установки очистки газа, имеющем меньшую по сравнению с резервуаром пробкоуловителя площадь поперечного сечения.

Подведем итоги. В результате проведенного анализа определен круг факторов негативного воздействия на процесс промысловой очистки продукции сеноманской залежи Ямбургского месторождения во входных сепараторах одноступенчатой установки очистки газа:

1. образование твердых отложений на внутренних устройствах входных сепараторов, вследствие присутствия в газожидкостном потоке твердых частиц;

2. высокое начальное содержание в сепарируемой среде капельной жидкости со значительной степенью ее диспергирования турбулентным потоком;

3. многократные перегрузки входных сепараторов с проектными внутренними устройствами, относительно расчетных нагрузок, как по газу, так и по жидкости;

4. «захлебывание» сепараторов, сопровождающееся интенсивным уносом из аппаратов с отсепарированным газом капельной жидкости, при 
прохождении из промысловой газосборной сети «жидкостных» пробок больших объемов;

Негативное воздействие вышеперечисленных факторов значительно снижает качество очистки скважинной продукции во входных сепараторах, укомплектованных проектными внутренними устройствами ГП 1181.04.01. Результаты неэффективной очистки известны:

- «зарастание» газо-проточных частей нагнетателей ГПА и связанное с этим сокращение межремонтных периодов работы газокомпрессорного оборудования,

- газо-абразивное изнашивание элементов нагнетателей ГПА и запорнорегулирующей арматуры, влекущее за собой увеличение финансовых затрат на проведение дорогостоящих ремонтов,

- снижение эффективности процесса абсорбционной осушки газа с потерей дорогостоящего гликоля, что сопровождается ростом энергетических затрат на регенерацию абсорбента и ухудшением качества товарной продукции и др.

\section{Выводы}

В заключительной части статьи необходимо отметить, что для преодоления негативного воздействия на качество промысловой очистки продукции скважин Ямбургского месторождения существует весьма небольшой набор технических решений.

Увеличение производительности входных сепараторов и повышение эффективности процесса промысловой очистки добываемой продукции, безусловно, связано с проведением модернизации внутренних сепарационных устройств в существующем корпусе сепараторов. Данный вывод подтверждается результатами проведенных институтом расчетов процесса сепарации. Институтом предложено проведение модернизации сепарационных элементов существующих аппаратов, что позволило бы увеличить как производительность сепарационного оборудования, так и эффективность очистки газа.

Преодоление негативного влияния на процесс промысловой очистки газа вышеперечисленных факторов возможно применением в составе модернизируемых внутренних устройств отбойных насадок, конструкция которых позволила бы обеспечить:

- равномерное распределение (во входном устройстве) по сечению аппарата без образования застойных зон и зон повышенных скоростей на входе в сепарационные секции потока с максимальным отделением из сепарируемой среды крупной фракции капельной жидкости и механической примеси;

— коалесценцию тонкодисперсной жидкостной фазы с последующей очисткой потока «сырого» газа от капельной жидкости в (концевой секции очистки) с регламентированным качеством;

— минимизацию гидравлического сопротивления аппарата и др.

$$
* * *
$$

1. «Новое оборудование для очистки природного газа перед промысло-вой ДКС на Ямсовейской месторождении». А.А. Пигарев, В.А. Толстов, М.В. Немцов, В.А. Соколов (ДОАО ЦКБН», Ю.А. Кудояр (ОАО «Газпром»), М.А. Малышкин (Надымгазпром). «Газовая промышленность». - 2008. № $1 .-$ C. $79-81$. 
2. Зиберт Г.К., Седых А.Д., Михайлов Н.В., Демин В.М. «Подготовка и переработка углеводородных газов и конденсата. Технологии и оборудование»: Справочное пособ. - М.: ОАО «Недра Бизнесцентр», 2001. - 316с.: ил.

3. «Совершенствование оборудования с прямоточными центробежными элементами». А.Г. Зиберт, Г.К. Зиберт, И.М. Валиуллин (ООО «УК «РусГа-зИнжиниринг». «Газовая промышленность». 2008. - № 9. - С. 72-74.

4. Синайский Э.Г., Лапига Е.Я., Зайцев Ю.В. «Сепарация многофазных многокомпонентных систем». М.: ООО «Недра - Бизнес центр», 2002. - 621с.; ил.

5. «Краткий справочник физико-химических величин». Изд. 8-е, пере-раб./Под ред. А.А. Равделя и А.М. Пономаревой. Л. : «Химия», 1983. - 232с., ил

6. «Основы массопередачи». Изд. 2-е, переработан. и дополнен. Учебное пособие для вузов. М., «Высшая школа», 1972. 496 с. с ил.

7. Чеботарев В.В. Расчеты основных технологических процессов при сборе и подготовке скважинной продукции: Учебное пособие. - Уфа: Изд-во УГНТУ. 1995. - 144 с.

8. «Прикладная гидродинамика газожидкостных смесей. M. Всероссий-ский научноисследовательский природных газов и газовых технологий. Ива-новский государственный эергетический университет. 1998г. 400с. Авт.: Г.Э. Одишария, А.А. Точигин.

9. Гриценко А.И., Клапчук О.В., Харченко Ю.А. «Гидродинамика га-зожидкостных смесей в скважинах и трубопроводах». М.: «Недра», 1994. - 238с.: ил.

10. «Движение газожидкостных смесей в трубах. М., «Недра», 1978, 270с. Авт.: В.А. Мамаев, Г.Э. Одишария, О.В. Клапчук и др.

11. Бекиров Т.М., Шаталов А.Т. «Сбор и подготовка к транспорту при-родных газов». - М.: «Недра», 1986. $-261 \mathrm{c}$.

12. Мильштейн Л.М., Бойко С.И., Запорожец Е.П. «Нефтегазопромысло-вая сепарационная техника: Справочное пособие/ Под ред. Л.М. Мильштейна. - М. «Недра», 1992. - 236 с.: ил.

13. Маслов В.М. Концепции анализа и совершенствования техники и тех-нологии промысловых подготовки и транспорта газа. Ташкент: «Фан», 1997.

14. «Сбор, транспорт и хранение природных углеводородных газов. Учебное пособие. М. «Недра», 1978, 405 с. Авт.: А.И. Гужов, В.Г. Титов, В.Ф. Медведев, В.А. Васильев. 


\title{
РАЗДЕЛ ІІІ. ЮРИСПРУДЕНЦИЯ
}

\author{
Алехина А.А. \\ Социально-правовая природа суда присяжных
}

Тамбовский Государственньй Технический Университет

(Россия, Тамбов)

doi:10.18411/spc-22-11-2018-03

idsp: spub-22-11-2018-03

Реформирование суда присяжный в современной России делает чрезвычайно актуальным вопрос о сущности этой формы судопроизводства. Социальное значение «идеальной модели» суда с участием присяжных заседателей трудно переоценить. Еще в XIX в. К. Миттермайер писал о великом значении суда присяжных по отношению к подсудимому: «...уже одно то обстоятельство, что они судятся своими согражданами, придает приговору большую силу и вместе с тем усиливает и действие как самого уголовного закона, так и правосудия».

Принцип участия граждан в работе органов государственной власти в рамках разных ее ветвей и разных уровней публичной власти многократно закреплен в отраслевом законодательстве, законах субъектов федерации и является базовым демократическим принципом, обусловленным существованием гражданского общества.

Конституция РФ прямо закрепила право участия граждан в отправлении правосудия (ч. 5 ст. 32 Конституции РФ). Конституционное законодательство также устанавливает, что «судебная власть в Российской Федерации осуществляется только судами в лице судей и привлекаемых в установленном законом порядке к осуществлению правосудия присяжных и арбитражных заседателей.

Задача участия общественности в работе судебных органов также очевидна и с политический точки зрения - это повышения адекватности принятия судебных решений запросам общества, увеличение соответствия общественных отношений и решений власти в области правоприменения, преодоление правового нигилизма, повышение транспарентности и качества правосудия, снижение риска судебных ошибок, продиктованных возможной профессиональной деформацией представителей судебного корпуса, коррупцией в системе судопроизводства.

Суд с участием присяжных заседателей демонстрирует больший воспитательный эффект, т.к. его вердикт в глазах общественности - это решение не только государственного органа власти, но и решение самой общественности. Также общественный контроль в системе судопроизводства повышает индивидуализацию, которая соответствует принципу дифференциации и индивидуализации в уголовном праве. Однако этот позитивный потенциал суда с участием присяжных заседателей в полной мере может быть реализован лишь в идеальной его модели, которая предполагает высокий уровень правосознания населения и, в первую очередь, присяжных заседателей, предусматривающих высокую степень их ответственности, уважение к закону, логичность и предсказуемость принимаемых ими решений и т.д., а также надлежащую процессуальную форму, в которую облачаются процесс и результат принятия решений судом с участием присяжных заседателей.

Социальная сущность суда с элементом народного представительства всегда вызывала разнообразную оценку его применения и эффективности, еще более значимые для нашей страны дискуссии звучат в связи с принятием новелл федерального законодательства, в частности закона, предполагающего расширение 
полномочий суда присяжных, чьи положения вступили в силу с 1 июня 2017 года, за исключением отдельных положений, вступающих в силу с 1 июня 2018 года.

В.К. Случевский писал: «Несмотря на торжество суда присяжных, на ту быстроту, с которой он в текущем столетии распространился по континенту Европы, спор о его достоинствах и недостатках до сих пор не может быть признан законченным. Высокоавторитетные процессуалисты группируются в отношении него на два враждебных лагеря, насчитывающие в своей среде горячих защитников и не менее ожесточенных противников».

Н.П. Герасимова отмечает: «В идеале суд присяжных - уменьшенная модель общества. В присяжные заседатели граждане попадают на основе случайной выборки, независимо от социального статуса, национальной принадлежности, пола, образования».

Особая социальная роль суда присяжных, а, следовательно, и особое его восприятие среди профессиональных юристов и граждан, основано на современной статистике. Так, статистка оправдательных приговоров говорит о том, что оправдательные вердикты судом присяжных выносятся значительно чаще, чем судом профессионалов.

К характеристике суда присяжных как к форме судопроизводства наиболее приложимы основополагающие принципы уголовного судебного процесса, в числе которых равенство прав сторон перед судом и их состязательность. В суде буквально, наглядно, осмысленно для присутствующих происходит состязание, борьба, защиты и обвинения через представление доводов, выводов и доказательств. В то же время в науке уголовного процесса указаны и многие проблемы в реализации этих принципов в суде с участием присяжных заседателей. Так, по мнению Е.П. Ищенко, избранные в состав коллегии присяжных граждане не просто не имеют опыта отстаивания общественных интересов при отправлении правосудия - психологически они не чувствуют себя «судьями факта» (т.е. судят было преступное деяние или нет), а пытаются максимально точно применить закон, конечно, в меру своего понимания и в соответствии с мастерством представления доказательств сторонами защиты и обвинения.

Популярность суда присяжных среди людей может быть связана с явлением правового нигилизма: недоверия органам власти, судам в том числе, и продуцируемым ими нормам, и решениям. Государственные органы власти воспринимаются (и могут являться) как коррумпируемые, поэтому незаслуживающими доверия и легитимности.

Т.А. Владыкина одним из недостатков системы судопроизводства с участием присяжных заседателей видит нехватку информации, в том числе первоначальной. Также к недостаткам относят то, что присяжные воспринимают информацию на слух, что позволяет манипулировать их сознанием, выстраивая психологически адекватно возможностям их восприятия речь и представление доказательств.

Наиболее распространенным взглядом на суд присяжных является взгляд на него как на форму уголовного судопроизводства. Однако, есть и другие подходы к его определению.

Суд присяжных может рассматриваться как орган государственной власти и даже как общественная организация. Так, Е. А. Киреева определяет суд присяжных в качестве «сложного государственного органа», утверждает, что его природа двояка. При исследовании особенностей суда присяжных можно выявить в коллегии присяжных много признаков, свойственных общественной организации: прежде всего, участие общественности, самоуправляемость, общая цель и некоммерческий характер. Однако коллегия присяжных не может являться общественной организацией и общественным объединением в полном (юридико-формальном) смысле слова, потому что своей основной деятельностью - осуществлением правосудия - сильно отличается от общественных объединений, как считает автор. Осуществление правосудия в России 
является функцией только государственных органов, к которым и относится суд присяжных, так как входит в состав судебной системы Российской Федерации. Добавим также, что формальные признаки, такие как устав, порядок учреждения и ликвидации, порядок регистрации, свойственные на основе действующего законодательства общественным организациям, совершенно не сопоставимы с организационными признаками коллегии присяжных заседателей и суда присяжных. Вероятно, более уместным было бы квалифицировать некоммерческую, общественную составляющую института присяжных заседателей через термин «общественное объединение».

Далее Е.А. Киреева обосновывает то, что суд присяжных «представляет собой орган государственной власти, потому что входит в государственный аппарат, обладает компетенцией, функциями и организацией государственного органа, однако имеет одну особенность - это особая процедура выбора членов и кратковременность состава». Отметим, что особая процедура выборов и кратковременность состава - довольно распространенные формально-юридические признаки государственного органа власти и управления. В некотором роде, особенные процедуры выборов установлены практически для любого органа публичной власти, формируемого с электоральным элементом, а кратковременность - признак существования органа власти, например, в условиях чрезвычайного положения. Ученый справедливо отмечает, что «при этом суд присяжных является таким органом государственной власти, в котором основную функцию судебного органа - осуществление правосудия - выполняют не только профессиональные судьи, но и представители общества. Поэтому правосудная деятельность суда присяжных реализуется в том понимании закона, в котором его понимает общество».

Юридическая доктрина и практика все время пытается примирить разные, представляющиеся противоположными, стороны явления суда присяжных: право человека на профессиональное быстрое судопроизводство, основанное на норме права в демократическом его контексте и право на справедливость, правосудие, основанное на справедливости.

$$
* * *
$$

1. О внесении изменений в Федеральный закон «О присяжных заседателях федеральных судов общей юрисдикции в Российской Федерации»: Федеральный закон от 23.06.2016 № 209-Ф3/ Доступ из справочно-правовой базы Гарант.

2. О государственной защите судей, должностных лиц правоохранительных и контролирующих органов: Федеральный закон от 20 апреля 1995 г. № 45-Ф3 // Собрание законодательства РФ. 1995, № 17, ст. 1455; 1998, № 30, ст. 3613; 1999, №2, ст. 18.

3. $\mathrm{O}$ народных заседателях федеральных судов общей юрисдикции в Российской Федерации: Федеральный закон от 02.01.2000 г. № 37-Ф3 / Доступ из справочно-правовой базы Гарант.

4. О присяжных заседателях федеральных судов общей юрисдикции в Российской Федерации: Федеральный закон от 20.08.2004 № 113-Ф3/ Доступ из справочно-правовой базы Гарант.

5. О федеральном бюджете на 2017 год и на плановый период 2018 и 2019 годов: Федеральный закон от 19.12.2016 № 415-Ф3 / Доступ из справочно-правовой базы Гарант.

6. Об арбитражных заседателях арбитражных судов субъектов Российской Федерации: Федеральный закон от 30.05.2001 г. N 70-Ф3 (ред. от 19.12.2016) / Доступ из справочно-правовой базы Гарант.

7. Об изменениях и дополнениях Конституции РСФСР: Закон РСФСР от 1 ноября 1991 г. // Ведомости СНД РСФСР и ВС РСФСР. 1991. №45. Ст. 1497.

8. Об общих принципах организации местного самоуправления в Российской Федерации: Федеральный закон от 06.10.2003 г. № 131-Ф3 / Доступ из справочно-правовой базы Гарант.

9. О мерах по завершению первого этапа судебной реформы: Распоряжение Президента РФ от 22 сентября 1992 г. №530-рп // Собрание актов Президента и Правительства РФ. 1992. №13. Ст. 1054.

10. Программа мероприятий по поэтапному введению суда присяжных и других принципиально новых положений процессуального и судоустройственного законодательства // Собрание актов Президента и Правительства РФ. 1992. №13. Ст. 1054.

11. О федеральной целевой программе «Развитие судебной системы России на 2013 - 2020 годы»: Постановление Правительства РФ от 27 декабря 2012 г. № 1406 / Доступ из справочно-правовой базы Гарант.

12. Об утверждении Правил финансового обеспечения переданных исполнительно-распорядительным органам муниципальных образований государственных полномочий по составлению списков 
кандидатов в присяжные заседатели федеральных судов общей юрисдикции в Российской Федерации: Постановление Правительства РФ от 23.05.2005 № 320 / Доступ из справочноправовой базы Гарант.

13. Об утверждении Порядка организации деятельности судебных приставов по обеспечению установленного порядка деятельности судов: Приказ Федеральной службы судебных приставов от 17.12.2015 № 596 / Доступ из справочно-правовой базы Гарант.

14. О государственной защите судей, должностных лиц правоохранительных и контролирующих органов: Модельный закон (принят постановлением на двенадцатом пленарном заседании Межпарламентской Ассамблеи государств - участников СНГ от 8 декабря 1998 г. N 12-9) / Доступ из справочно-правовой базы Консультант

15. Рекомендации о порядке составления списков присяжных заседателей: Министр юстиции Российской Федерации. от 30.09.1993 г. / Доступ из справочно-правовой базы Консультант.

16. Состояние судебной системы и ее взаимодействие с другими ветвями власти в современном демократическом государстве: Заключение Консультативного Совета Европейских судей для Комитета Министров Совета Европы N 18(2015) / Доступ из справочно-правовой базы Консультант.

17. Новгородская судная грамота. 1471 г. / Российское законодательство X-XX Законодательство Древней Руси. М., 1984. С. 303-304.

18. О революционном трибунале, его составе, делах, подлежащих его ведению, налагаемых им наказаниях и о порядке ведения его заседании: Инструкция народного комиссариата юстиции от 19.12.1917 г. / Доступ из справочно-правовой базы Консультант.

\section{Лисицына Е.Н. \\ Правовая природа прецедентного нормотворчества европейского суда по правам человека}

Тамбовский государственный технический университет (Россия, Тамбов)

doi: 10.18411/spc-22-11-2018-04

idsp: spub-22-11-2018-04

В том, что касается нормотворчества Европейского Суда по правам человека, среди исследователей сегодня нет существенных разногласий. В силу того, что решения Суда не обладают обязательной юридической силой для национальных судов, решения Европейского Суда трудно назвать прецедентами в полном смысле этого слова. При этом судебная практика является источником права - это также признается всеми. В качестве примера можно указать статью 6 Конвенции, которая не предусматривает защиту права на доступ к правосудию, но которое, тем не менее, однозначно признано Судом именно на основании данной статьи.

Важно отметить причину, по которой Европейский Суд придерживается прецедентной практики по своим делам. Во-первых, стоит отметить, что система прецедентов предоставляет в наибольшей степени свободу в толковании Конвенции, нормы которой сформулированы довольно скупо. Во-вторых, эволютивный подход Европейского Суда к толкованию норм Конвенции требует постоянно повышающейся эффективности применения ее норм. Эту же точку зрения разделяет Энтин М.Л. В комментарии к разделам о конвенционных контрольных органах он пишет: «однажды проиграв дело, государство может быть уверено в том, что и по всем другим жалобам аналогичного характера будут вынесены такие же решения.... Поэтому все участники Конвенции заинтересованы в том, чтобы на постоянной основе отслеживать практику ее контрольных органов, не принимать противоречащие этой практике нормативные акты ....».

Таким образом, можно сделать вывод о том, что система прецедентов Европейского Суда позволяет сохранять преемственность применения норм права, выработанных в рамках Конвенции, при этом оставляя возможность гибкого развития механизма защиты прав человека по мере общественного развития. Более того, необходимость следовать прецедентному праву находит отражение и в самой практике Европейского Суда. 
Так, например, в решении по делу Косси Суд подчеркнул, что следование прецедентам позволяет придерживаться принципа «правовой определенности и законных ожиданий». В процессе применения прецедентов нельзя обойтись без явных нормативно-правовых обобщений, которые и представляют собой результат нормотворчества Европейского Суда. Как указывает Люциус Вильдхабер, Председатель Европейского Суда, «прецедентам следуют регулярно... для достижения единообразия, последовательности и определенности». В таком случае применение нормы права, закрепленной в предыдущем судебном решении, зависит от совпадения фактов каждого последующего дела, поскольку мотивировка решения в данном случае должна совпадать. Европейский Суд указал в вышеупомянутом решении по делу Косси, что отклонение от ранее принятых решений будет возможно лишь по «убедительным основаниям», среди которых может быть необходимость дальнейшей эволюции права Конвенции, чтобы «толкование Конвенции отражало изменения в обществе и находилось в соответствии с требованиями сегодняшнего дня».

Ученые признают, что Европейский Суд следует нормам права, принятым в решениях в предыдущих делах, но также подчеркивает ряд трудностей, с которыми приходится сталкиваться при определении единого ratio decidenti, т.e. мотивировки решения, что составляет квинтэссенцию прецедента. В качестве примера подобных трудностей можно привести вопрос о высылке «иммигрантов второго поколения» или «интегрировавшихся иностранцев». Вильдхабер считает, что потребовался целый ряд решений для того, чтобы выработать прецедент: начиная от дела Мустакима (решение от 18 февраля 1991 года) и заканчивая делом Буйлифа (решение от 21 октября 1997 года).

Учитывая эти сложности, Европейский Суд в своей практике выработал порядок «отделения» более ранних дел. Так, например, если факты по делу идентичны или существенно сходны с теми, которые фигурировали в предыдущем деле, Европейский Суд стремится применять ту норму права, которая была разработана в прецеденте. Лишь в том случае, когда факты по делу существенно отличаются, применяется методика «отделения более ранних дел». В качестве примера такого «отделения» можно привести серию дел, связанных с вопросом максимально допустимого срока предварительного заключения. Так, например, в деле Томази против Франции Суд сформулировал норму права, согласно которой предварительное заключение длительностью 5 лет и 7 месяцев не может быть оправдано ничем, включая необходимостью защиты свидетелей и общественного порядка, а также особой сложностью дела. В данном решении факты были таковы: против Томази было выдвинуто обвинение в организации вооруженного нападения, в результате которого погиб один человек и еще один получил серьезные увечья. В другом деле, где были установлены практически идентичные обстоятельства дела, W. contre Suisse280 Заявитель в данном деле был обвинен в мошенничестве с использованием служебного положения и совершении ряда других преступлений. В ходе судебного слушания, которое длилось более 4 лет, он находился в предварительном заключении. В данном деле Европейский Суд признал обоснованность столь длительного содержания под стражей (превышающего 4 года) лишь в случае «исключительных обстоятельств», таких как особая сложность совершенного преступления, а также для охраны общественного порядка и предотвращения давления на свидетелей. Таким образом, «выделение», т.е. ситуация, когда Европейский Суд не следует решениям по предыдущим делам, представляет собой не столько создание нового прецедента, а развитие уже имеющегося.

Два решения по делам с идентичными обстоятельствами содержат различные нормы, касающиеся определения правомерности продления предварительного заключения. 
Из всего вышесказанного можно сделать вывод: доктрина прецедента широко применяется в Европейском Суде по правам человека. Как представляется, слияние Суда и Комиссии будет способствовать лишь развитию нормотворчества. Европейского Суда, позволит создать более оперативную, эффективную и четкую систему защиты прав человека на европейском уровне. Практика Суда и доктрина прецедента будет соблюдаться, если нет непреодолимых, серьезных и объективных причин не соблюдать их.

Кроме того, стоит упомянуть о том, что именно в этом, по всей вероятности, и заключалась сама идея деятельности Суда по правам человека, выраженная в статье 35 Конвенции. Статья 35, в которой речь идет об условиях приемлемости жалоб, подаваемых в Европейский Суд, говорит: «Суд не принимает никакую индивидуальную жалобу...., если она ... является по существу аналогичной той, которая уже была рассмотрена Судом».

Особенность системы прецедентов, созданной Европейским Судом по правам человека, заключается в том, что решения Суда лишены четкого правового механизма их реализации в государствах-членах. Согласно статье 46 Конвенции, государства участники «обязуются исполнять окончательные постановления Суда по делам, в которых они являются сторонами». Однако даже Комитет министров, которому по той же статье поручено осуществлять надзор за исполнением решений Суда, не имеет реального механизма принуждения государства к исполнению решения.

$$
* * *
$$

1. Конституция Российской Федерации (принята всенародным голосованием 12.12.1993) (с учетом поправок, внесенных Законами РФ о поправках к Конституции РФ от 30.12.2008 N 6-ФКЗ, от 30.12.2008 N 7-ФКЗ, от 05.02.2014 N 2-ФКЗ, от 21.07.2014 N 11-ФКЗ).

2. Всеобщая декларация прав человека. Принята резолюцией 217 А (III) Генеральной Ассамблеи ООН от 10.121948 г. / Доступ из справочно-правовой системы Гарант.

3. Регламент Европейского Суда по правам человека (ред. От 01.01.2016 г.) [Электронный ресурс] / URL: http://www.echr.coe.int/Documents/Rules_Court_RUS.pdf (дата обращения 25.11.2017).

4. Устав Совета Европы (Лондон, 5 мая 1949 года) // Собрание законодательства РФ. 1997. № 12. Ст. 1390.

5. Analysis of statistics 2016. [Электронный pecypc] / URL: http://www.echr.coe.int/Documents/Stats_analysis_2016_ENG.pdf (дата обращения 25.11.2017).

6. Charter of Fundamental Rights of the European Union (N̄ice, 7 December 2000) [Электронный pecypc] / URL:

https://www.cvce.eu/obj/charter_of_fundamental_rights_of_the_european_union_nice_7_december_2000en-bd4834f5-deff-4ad0-abdf-071ae-4a85edf.html (дата обращения 25.11.2017).

7. Европейское право. Право Европейского Союза и правовое обеспечение защиты прав человека: Учебник для вузов / под ред. Л. М. Энтина. М., 2007. 380 с..

8. Кучин М.В. Прецедентное право Совета Европы и правовая система РФ: проблемы взаимопонимания // Правоведение. 2001. № 1. С. 50-52.

\section{Переверзева А.Е. \\ Деформация личности адвоката и юридические последствия проявления данного феномена}

Челябинский государственный университет (Россия, Челябинск)

doi:10.18411/spc-22-11-2018-05

idsp: spub-22-11-2018-05

Избрание в качестве профессиональной деятельности адвокатуру автоматически возлагает на лицо определенные требования относительно гражданской позиции, внутреннего «морального стержня», нравственных ценностей и принципов, психического и духовного здоровья. «Издержки профессии» нередко являются причиной профессиональной деформации личности адвоката, крайней формой выражения которой является правовой нигилизм. Крайняя степень такого 
мировоззрения может стать одной из предпосылок, по которым адвокат умышленно нарушает закон или совершает попытку «его обойти». В данном случае правовая деформация личности адвоката может поставить под угрозу как общественные отношения, охраняющие осуществление государственной власти, правоохранительной, следственной деятельности или правосудия. Опасность также выражается в причинении вреда правам, свободам и законным интересам самого доверителя.

Негативные свойства личности толкают адвокатов не только на правовые проступки, но и на преступления, что неизбежно влечет за собой утрату адвокатского статуса. За 2017 год на территории Российской Федерации адвокатскую деятельность осуществлял 78941 адвокат. Так, в 2017 году в дисциплинарном порядке статус прекращен 367 адвокатам $(0,47 \%)$. На основании неисполнения или ненадлежащего исполнения своих обязанностей перед доверителем статуса были лишены 63 (0,08 \%) адвоката; 112 (0,16 \%) адвокатов были лишены статуса за нарушение норм профессиональной этики; $157(0,20 \%)$ - за неисполнение или ненадлежащее исполнение решений органов адвокатской палаты; 29 (0,4\%) - за непредставление сведений об избрании формы адвокатского образования; $6(0,007$ \%) - за представление недостоверных сведений в квалификационную комиссию. В связи с осуждением за совершение умышленного преступления 34 (0,04 \%) адвоката были лишены своего статуса.

Значительная часть уголовных дел с участием адвокатов квалифицируются как мошенничество, дача взятки или посредничество во взяточничестве и совершаются в процессе осуществления профессиональной деятельности.

За январь-сентябрь 2016 года во Всероссийскую антикоррупционную общественную приемную "Чистые руки" поступило 9125 жалоб. Содержание 77,5\% от общего числа сводилось к фактам коррупции в судах. За этот же период средний размер взятки по уголовным делам составил 2 миллиона рублей, по гражданским делам - около 720000 руб. Специалисты общественной приемной заявляли о том, что сумма взятки за отказ полиции возбуждать уголовное дело не превышала полутора миллиона рублей. Также специалисты заключили о сокращении числа жалоб на прокуратуру - с 33,75\% за прошлый период до 15,8\% за период, указанный выше.

В большинстве случаев посредниками в таких взятках являются адвокаты. Гонорары, которые они требуют за осуществление такого рода деятельности обычно колеблются в пределах 3-5 миллионов рублей. Так, в 2008 г. сотрудник УБЭП ГУВД Челябинской области С. Якубовский пообещал руководителю компании «Мост» В. Давыдову прекратить в отношении него уголовное преследование за вознаграждение в 5 млн руб. Посредниками при передаче взятки были адвокаты Сергушкин и Надершин. Сергушкина задержали сотрудники ФСБ при получении денег, после чего следствие вышло и на остальных участников дела.

Сотрудник УБЭП ГУВД был приговорен к пяти годам условного осуждения с запретом на работу в правоохранительных органах в течение двух лет. В качестве дополнительного наказания на С. Я. был наложен штраф в сумме 700000 руб. Адвокаты были приговорены к 2 г. условного осуждения.

В 2010 году адвокат Межуев, доверительница которого обвинялась в совершении ряда экономических преступлений, сообщил последней заведомо ложные сведения о необходимости передачи судье взятки в размере 3 миллионов рублей для того, чтобы был вынесен оправдательный приговор. Адвокат был задержан в момент передачи части суммы, за что был приговорен к 5 годам лишения свободы с отбыванием наказания в исправительной колонии общего режима.

Таким образом, проблемы коррупции в органах правосудия, правоохранительных органах и деформации личности адвоката находятся в тесной взаимосвязи. Данная проблема может быть решена специфическими методами, направленными непосредственно на адвоката, а также такими мерами, которые 
способствовали бы формированию нравственно здоровой нации. Деформация личности адвоката - явление, которое зависит не только от его персональных качеств, но и социальной среды, в которой он себя реализует в самых различных социальных ролях. Должностные лица правоохранительных органов и органов правосудия, доверители, коллеги, близкие лица - субъекты, которые в той или иной мере влияют на формирование и проявление у адвокатов деформации личности.

Несмотря на то, что имеющий судимость адвокат не вправе заниматься адвокатской деятельностью, правовые нормы не содержат запрета на осуществление таким лицам деятельности в сфере оказания юридических услуг. Целесообразно будет на законодательном уровне ввести запрет на осуществление юридической деятельности в целом. Целесообразно будет судам в качестве дополнительного вида наказания использовать не «запрет на осуществление адвокатской деятельности», а любых видов юридической деятельности. Юрист является лицом, профессия которого обязывает к уважению закона. Имеющее снятую и даже погашенную судимость лицо не достойно осуществлять юридическую деятельность.

Кроме того, страх перед наказанием, которое повлечет за собой бессрочное лишение права заниматься деятельностью, приносящей доход, будет иметь превентивную функцию. Такая мера уголовно-правового характера будет дополнительным гарантом того, что юридическую деятельность осуществляют лица, уважающие закон и права человека.

Более того, каждый двухсотый адвокат в 2017 году был лишен статуса в дисциплинарном порядке, что свидетельствует о том, что меры воздействия не являются эффективными. Увеличить объективность принимаемых решений по делам о привлечении адвокатов к дисциплинарной ответственности позволило бы изъятие данного правомочия у палаты адвокатов и передать их органу государственной власти (например, Министерству Юстиции).

Также молодежная и образовательная политика нуждаются в реформировании. Необходимо формирование и внедрение новых методов морального воспитания общества - это не только условие понижения коэффициента развития деформации личности адвоката, юристов, или российского общества в целом, а гарант развития и становления правового государства, защищенности от негативного влияния правонарушителей прав, свобод и законных интересов личности. Правовой нигилизм достаточно распространенная в российском обществе тенденция. Невозможно построить правовое государство и развитое гражданское общество там, где уважение к праву и здоровое понятие справедливости и честности отсутствует даже у юриста.

$$
* * *
$$

1. Ашалдаева В., Романов Д., Взятки с особым статусом. Адвокаты. [Электронный источник] // Право.ru URL: https://pravo.ru/story/view/50183/ (дата обращения: 23.10.2018).

2. Боровков А. В., Караев С. Т. Современные проблемы нравственного регулирования деятельности адвоката в РФ [Текст] // Юридические науки: проблемы и перспективы: материалы II Междунар. науч. конф. (г. Пермь, январь 2014 г.). - Пермь: Меркурий, 2014. — C. 74-76. - URL https://moluch.ru/conf/law/archive/113/4806/ (дата обращения: 18.11.2018).

3. Информационная справка о состоянии адвокатуры и адвокатской деятельности в 2017 г. [Электронный источник] // Федеральная палата адвокатов. URL: https://fparf.ru/ (дата обращения: 23.10.2018).

4. Коррупция в России: Независимый годовой доклад ВАОП «Чистые руки» [Электронный источник] // M., 2016 г. - C. 26.

5. Лизнева, Д. С. Нравственность в профессии адвоката-защитника по уголовным делам [Электронный источник] // Научное сообщество студентов ХХІ столетия. ГУМАНИТАРНЫЕ НАУКИ: сб. ст. по мат. XIV междунар. студ. науч.-практ. конф. № $14 . \quad$ URL: http://sibac.info/archive/humanities/guman8(11).pdf (дата обращения: 18.11.2018) 
Тузкова А.A.

\section{Проблемы судопроизводства по делам, связанным с возмещением вреда здоровью в лечебных учреждениях}

Пензенский Государственный Университет (Россия, Пенза)

doi:10.18411/spc-22-11-2018-06

idsp: spub-22-11-2018-06

Основной проблемой судопроизводства по делам, связанным с возмещением вреда здоровью является отсутствие понятийного аппарата медицинского права на законодательном уровне.

Примером неправильного понимания медицинскими работниками основных категорий медицинского права является типичный взгляд на «информированное добровольное согласие на медицинское вмешательство или на отказ от него» как на инструмент защиты от возможных преследований. Большинство медицинских работников считает, что согласие на медицинское вмешательство освобождает их от ответственности за причинение вреда.

Еще одной проблемой в правоприменительной и судебной практике является общая коррумпированность системы, например, в плане судебно-медицинской экспертизы, а также фальсификации медицинской документации по спорному делу.

Остановимся подробнее на объективности судебно-медицинской экспертизы, так как именно заключение по данной экспертизе по делам о медицинской деятельности является одним из основных доказательств, которое позволяет суду проследить связь между состоянием пациента и назначенным ему лечением.

Так, ряд ученых - правоведов указывают на возможную необъективность судебно-медицинской экспертизы. Например, Е.Л. Козьминых указывает на то, что привлечение экспертов, принадлежащих к одному территориальному ведомству здравоохранения, не обеспечивает независимости медицинских экспертов в объективном смысле.

Этот же недостаток изучали Саверский А.Л. и Старченко А.А., которые указывают, что в большинстве случае медицинским экспертом по определениям судей выступает бюро судебно-медицинских экспертиз, которое в соответствии с утверждённой Минздравом России номенклатурой медицинских организаций является «медицинской организацией особого типа», которое входит в территориальную систему здравоохранения и не может участвовать в судебном процессе в силу подчиненности солидарному ответчику по такого рода делам - органу управления здравоохранения в данном регионе».

Нивелировать указанные недостатки возможно путем назначения и проведения судебных экспертиз в независимых экспертных организациях (в частности, в лабораториях судебной экспертизы Минюста России), которые имеются в большинстве областей России, либо направлять дела для производства экспертизы в другие регионы.

В этой связи, по нашему мнению, привлечение специалистов к процессу по гражданским делам о причинении вреда здоровью при оказании медицинских услуг, является обязательным. Более того, необходимо проводить двухуровневую оценку причиненного вреда: предварительную оценку специалистом и заключительную оценку судом.

Кроме того, часто в научных кругах указывают на особенности ведения медицинской документации медицинским учреждением-ответчиком, в силу которых она может быть фальсифицирована и потому «не может выступать в качестве источника объективных критериев оценки объема и качества медицинской помощи». 
Данную возможность можно пресечь путем внедрения электронных карт больных, что позволило бы пациентам в любое время знакомиться со своей медицинской картой через Интернет, осуществлять копирование документов из неё при возникновении такой необходимости.

Еще одной проблемой является отсутствие единых стандартов экспертной оценки, отсутствие четких, алгоритмических методических пособий. Так, правоведыпрактики отмечают часто встречающуюся непоследовательность мнений экспертов по сходным клиническим случаям, что свидетельствует об отсутствии неких единых стандартов экспертной оценки. Решением данной проблемы может выступить создание и внедрение когнитивных экспертных систем, сервисы которых могут предоставить доступ к медицинским классификаторам и интерактивным инструментам для клинической практики.

Таким образом, необходимо более детально на законодательном уровне проработать вопросы, связанные с установлением оснований и условий ответственности, так как отсутствуют единые стандарты экспертной оценки, а также весьма неоднозначно могут трактоваться действия медицинского работника в конкретной ситуации.

Необходимо также дальнейшее совершенствование действующей нормативноправовой базы в сфере здравоохранения путем систематизации и кодификации законодательных актов, в целях понятного и однозначного определения порядка и условий ведения профессиональной медицинской деятельности.

Для устранения существующих проблем следует разрешить и ряд прикладных вопросов, например, повышения эффективности обучения медицинских работников и постоянной переподготовке и повышении квалификации опытных специалистов. Для этого необходимо развитие существующих образовательных программ, внесение в них корректировок с учетом передовых медицинских технологий, постоянное обновление учебной базы.

Одним из факторов, позволяющих определить виновность или невиновность, является отношение медицинского работника к его профессиональным обязанностям. В случае подтверждения проявления им необходимых в складывающейся ситуации осмотрительности и заботливости, медицинский работник должен признаваться невиновным в причинении вреда.

Помимо указанных направлений, целесообразно было бы предусмотреть обязательное страхование ответственности медицинских работников перед пациентами на законодательном уровне, что могло бы гарантировать пострадавшему возмещение ущерба причиненного его здоровью в любом случае.

При определении размеров возмещения вреда во внимание также должны браться и дополнительные расходы, вызванные неисполнением обязательств по гражданско-правовым договорам, заключенным при жизни умершего, если финансовое положении членов семьи не позволяет исполнить принятые им обязательства.

$$
* * *
$$

1. Козьминых Е.Л. Судебная экспертиза по «врачебному делу» // Российская юстиция. 2015. № 3.

2. Поляков И.Л. Ответственность по обязательствам вследствие причинения вреда.- М.: Юрист, 2018.C. 34 .

3. Саверский А.Л. Старченко А.А. О необходимости передачи сети бюро судебно-медицинских экспертиз под ведомство Росздравнадзора // Медицинское право. 2016. № 1.

4. Цыганова О.А. Российская судебная практика по разрешению дел о возмещении вреда, причиненного жизни и здоровью граждан при оказании медицинской помощи: проблемы и перспективы / О.А.Цыганова, Т.Г. Светличная, И.В. Ившин // Заместитель главного врача. - 2016. 


\title{
РАЗДЕЛ IV. ПЕДАГОГИКА
}

\author{
Шатская О.В. ${ }^{1}$, Войтик И.А. ${ }^{2}$ \\ Структурирование исполнительской (координационно-мышечной) \\ специфики дисциплин в системе дополнительного образования \\ на примере академического вокала \\ ${ }^{1}$ МБУДО ДДТ «Родник» \\ ${ }^{2}$ Театр «Наш дом» \\ (Россия, МО, Химки)
}

doi:10.18411/spc-22-11-2018-07

idsp: spub-22-11-2018-07

\section{Аннотация}

Статья посвящена структурированию исполнительской специфики творческих дисциплин в дополнительном образовании, на примере академического вокала. Выделены два практико-ориентированных уровня таких структур: уровень когнитивной практики и уровень исполнительских (координационно-мышечных) технических навыков. Показано, как в академическом вокале может быть выделено ядро вокально-исполнительской технической компетентности.

Ключевые слова: система дополнительного образования; исполнительская специфика; координационно-мышечные технические навыки; вокальноисполнительская компетентность.

\section{Abstract}

The article is devoted to the structuring of performing specificity of creative disciplines of additional education on the example of academic vocal. Two practice-oriented levels of such structures are distinguished: the level of cognitive practice and the level of performing (coordination-muscular) technical skills. It is shown how the core of vocalperforming technical competence is chosen in the academic vocal.

Key words: system of additional education, performing specificity, coordinationmuscular technical skills, vocal-performing competence.

Музыка - как феномен культуры и универсальный язык, в современном обществе приобретает особое значение. Однако процессы глобализации, происходящие в мире, экономический спад, наблюдаемый в последние годы, и другие социальноэкономические факторы, привели к тому, что уровень преподавания музыкальных дисциплин снижаетсяся, особенно - на исполнительском уровне: невозможно представить, что кто-либо учит другого человека управлять автомобилем, сам навыком вождения не владея [5].

Особый характер исполнительских навыков в академическом вокале и других музыкально-исполнительских дисциплинах, в отличие от процессов продуктивного мышления, основан на формировании особого (профессионально ориентированного) мышечного опыта и мышечной координации, в системе осознанной (волевой) саморегуляции.

Учитывая, что предметное (допрофессиональное) становление обучающихся современной педагогикой трактуется как активное саморазвитие субъектов деятельности (Ананьев, А.В. Брушлинский, Л.С. Выготский, П.Я. Гальперин, О.А. 
Конопкин, А.Н. Леонтьев, В.С. Мерлин, А. К. Осницкий, С.Л. Рубинштейн и др.), отсутствие общепринятых представлений о структуре исполнительской компетентности и особенностях предметной специфики некоторых исполнительских дисциплин, свидетельствует о недостаточности исследований по проблеме структурирования исполнительства в дополнительном образовании.

На важность структурирования специфики профессиональной исполнительской деятельности указывали С.Я. Батышев, А.А. Вербицкий, Э.Ф. Зеер, М. Ильязова, В.В. Сериков и др.; в основе - дифференциация таких составляющих, как знания, умения, навыки, способности, опыт; с дополнением их мотивационно-ценностными компонентами профессиональной деятельности (К.А. Абульханова-Славская, В.Д. Введенский, И.А. Зимняя, Дж. Равен, Н. Хомский, В.Д. Шадриков и др.).

В Законе об образовании РФ (статьи 82-85), также указывается на необходимость особой оценки профессиональной деятельности в некоторых дисциплинах.

В статье 82 Закона об образовании «Особенности реализащии профессиональных образовательных программ медицинского образования и фармацевтического образования〉 отмечается, что в данной предметной деятельности совершенствование профессиональных знаний и практических навыков должно оцениваться на протяжении всей жизни (вероятно, вы с большим доверием отнесетесь к хирургу с опытом, но в то же время учтете, что у пожилых врачей возможно ухудшение зрения, тремор рук и другие проявления физиологического характера).

В «Особенностях реализации образовательных программ в области искусства» (83 статья Закона об образовании) условия предыдущей статьи дополняются: кроме разработки интегративных профессиональных программ для выделенных творческих специальностей искусства на предпрофессиональном уровне, с ранним развитием профессиональных способностей (формирование профпригодности); с отбором детей, способных к соответствующей сфере профессиональной деятельности; предусматривается профессиональный уровень подготовки, программы которой предусматривают большой объем учебной и производственной практики в оговоренных дисциплинах искусства.

Статья 84 «Особенности реализаџии образовательных программ в области физической культуры и спорта» - как и статья 83 данного Закона, предусматривает интегральные образовательные программы специальной спортивной подготовки, с выявлением лиц, имеющих способности в сфере ФК и спорта; а также формулируются организационные условия реализации интегральных спортивных программ.

Статья 85 Закона об образовании выделяет особые требования к профессиональной компетентности работников транспорта, в результате которых должны быть выработаны практические навыки на уровне «употребления» - владение соответствующей профессиональной компетентностью на практике. С этой целью, например, в гражданской авиации введен норматив по лётной практике, [2].

Формирование мылечных навыков - необходимый компонент профессиональной компетентности в медицине, туризме, лингводидактике.

В системе дополнительного образования можно отметить необходимость разработки структуры исполнительства в таких творческих дисциплинах, как вокал, музыкально-инструментальное исполнительство, ИЗО, технология ручного творчества, хореография, а также - физкультурно-спортивные дисциплины, краеведение и туризм. 
На психолого - педагогическом уровне практическую специфику деятельности можно охарактеризовать как:

- когнитивную готовность (универсальная природа когнитивной готовности формируется на уровне продуктивного мышления, не требует специальных мышечных навыков и координации);

- владение исполнительскими навыками (основа - мышечная память и координация мышц, с непроизвольным личностно-ориентированным характером формирования индивидуальных исполнительских навыков на практике).

В то же время в музыкальном исполнительстве, в вокале, например, как свидетельствует международный опыт, исполнительство имеет универсальную природу, [3].

Научно-обоснованное структурирование исполнительства, как деятельности, состоит в выявлении характеристик исполнительской (практико-ориентированной) техники; по А.А. Вербицкому - операционально - инструментальной компетентности, когда в каждом виде исполнительства формируется своя мышечная техника.

Ядро музыкального исполнительства - мышечные автоматизмы; (Г.П. Прокофьев: инструментальная техника у пианистов - «..основные мышечные автоматизмы рук...»).

Более подробный анализ инструментального характера профессиональной специфики исполнительских дисциплин произведен авторами на примере вокала.

Голос человека - уникальный музыкальный инструмент, в котором профессиональная (вокально-исполнительская) компетентность всегда проявляется индивидуально, как неоднократно подчеркивал Л.Б. Дмитриев, врач-фониатр, ученый исследователь и вокальный педагог, [1].

На основании анализа научно-исследовательских публикаций по вокальной подготовке, авторы выделили 7 основных исполнительских компетенций в вокале (певческое дыхание; певческую позицию; певческие автоматизмы гортани (в первую очередь, сформированность опоры звука и выпевания певческих гласных); профессиональный диапазон; певческую артикуляцию; резонаторный самоконтроль и вокальный слух) [6].

Интегрированный, практико-ориентированный характер вокальной подготовки (исполнительство, как телесный опыт - сформированный мышечно-координационный комплекс); показывает, что при обучении вокалу невозможно игнорировать как природу формирования кинестетических вокально-мышечных синтезов бессознательной, безусловно-рефлекторной природы, так и условно-рефлекторную произвольную регуляцию формирования вокальной техники [4].

В условиях, когда педагогической наукой однозначно не структурированы исполнительские компетенции, педагогу дополнительного образования для их дифференциации необходимо работать вместе с психологом, основываясь на психофизиологических закономерностях предметных мышечных комплексов, лежащих в основе исполнительских навыков. Наиболее актуальны в дополнительном образовании мышечные навыки рук, пальцевая техника и координация (инструментальное исполнительство, технология ручного творчества, различные виды изобразительного искусства).

Осознанная саморегуляция обучающихся при формировании исполнительской техники - актуальная прикладная психолого-педагогическая проблема, которая может 
быть решена в исполнительских дисциплинах только на основе структурирования соответствующих технических компетенций.

$$
\text { *** }
$$

1. Дмитриев Л.Б., Солисты театра Ла Скала о вокальном искусстве, М, 2001 г.

2. Федеральный Закон «Об образовании в Российской Федерации» от 29.12.2012 № 273-ФЗ.

3. Мирошникова О.X. Профессиональный стандарт педагога: международный опыт и региональные компоненты. // Интернет-журнал «Науковедение», Т.7, № 3 (2015). - doi:10.15862/53PVN315

4. Осницкий А.К. Психологические механизмы самостоятельности. -М.; Обнинск: ИГ-СОЦИН. -2010. $-232 \mathrm{c}$.

5. Сорокоумова Е.А., Шатская О.В. Структура психолого-педагогического обеспечения личностноориентированного обучения вокалу в системе дополнительного образования // Известия Самарского НЦ РАН. Том 15. № 2(4). - 2013.- С.981-985.

6. Voytik I.A., Shatskaya O.V. Metodological foundations of teaching practict support of vocal training // Scientific Discussion, Vol 1, No 2 (2016), Praga, Czech Republic, ISSN 3041-4245. - 2016. - s 45-49. 


\section{РАЗДЕЛ V. ПСИХОЛОГИЯ}

\section{Кадырбаева Н.Р., Дмитриева Л.Г. Межличностные отношения в воинском коллективе}

Башкирский Государственный Педагогический Университет им. М. Акмулльл

(Россия, Уфа)

doi:10.18411/spc-22-11-2018-08

idsp: spub-22-11-2018-08

Проблема межличностных отношений в воинском коллективе является объектом изучения не только социальной психологии, но и таких междисциплинарных наук, как история, философия, конфликтология и социология. В психологии данная проблема и по сей день вызывает острый интерес у ученых и практиков. Это объясняется рядом причин. Важнейшая из них заключается в том, что все мы - участники межличностного взаимодействия. Каким образом происходит процесс становления и развития межличностных отношений, насколько он осмысленный и управляемый, что в нем определяется внешними обстоятельствами, а что внутренними качествами личности эти и многие другие вопросы постоянно возникают перед нами. И от того, как они будут решены, зависит морально-психологическое состояние личности, ее умение поддерживать взаимоотношения внутри коллектива.

Большинство современных исследователей данной проблематики (Г.М. Андреева, Б.Г. Ананьев, А.В. Петровский и др.) выделяют следующие виды межличностных отношений: кооперация, конкуренция (борьба, соперничество), межгрупповой конфликт и отношения независимости. А.В. Петровский характеризовал межличностные отношения как субъективно переживаемые связи между людьми, которые объективно проявляются в характере, способах межличностного взаимодействия.

По теории А.В. Петровского, межличностные отношения в малой группе имеют двойственную природу. Поверхностный слой межличностных отношений, который проявляется в каждой малой группе, образует систему эмоциональных притяжений и отталкиваний, но в коллективе возникает еще один слой межличностных отношений с характерными целями и мотивами общей совместной деятельности.

Многогранность и неоднозначность социальных процессов, происходящих в воинских коллективах, требуют разносторонней оценки, как самих военнослужащих, так и взаимоотношений между ними. Многие военнослужащие иногда неправильно истолковывают отношение к себе своих сослуживцев. Не все могут четко пояснить себе причину предвзятого к ним отношения. Хотя любой военнослужащий должен понимать, что каждая личность уникальна по привычкам, наклонностям, характеру, уровню образования, и другим личностным особенностям. Решить любые проблемы, возникающие внутри коллектива, можно только тогда, когда царит атмосфера дружбы, взаимопонимания и войскового товарищества.

Каждая воинская часть предназначена для выполнения определенных задач, связанных с поддержанием высокой боевой готовности всей армии. Для повышения боеготовности военнослужащих необходим дружный и сплоченный коллектив. Уровень выполнения этих задач наглядно демонстрирует, насколько эффективно действует организация жизнедеятельности воинского коллектива, а также зависит от характера взаимодействия. Положительный характер повышает результативность служебно-боевых задач, отрицательный - разрушает коллектив, усложняя совместную деятельность. Взаимопонимание и взаимовыручка, морально-психологическая 
готовность военнослужащих - залог успешного выполнения поставленных боевых задач.

Для грамотного управления военнослужащими, воинскими коллективами, необходимо иметь знания о социально-психологических особенностях каждого подчиненного, его слабые и сильные стороны. Также непосредственное влияние на качество индивидуальной и совместной деятельности военнослужащих оказывает характер взаимоотношений между ними. Полное взаимопонимание позволяет установить благоприятные взаимоотношения между военнослужащими: уважение, доверие, внимательность, отзывчивость и др., а также помогает исключить вероятность возникновения неуставных взаимоотношений. Учитывая это, старшие командиры должны постоянно заботиться о повышении морально-психологического состояния вверенного им коллектива, проводить индивидуальные беседы с каждым военнослужащим, организовывать спортивные мероприятия и культурно-массовый досуг.

Особенности военной службы порождают особый вид взаимоотношений в воинских коллективах. В ней чаще всего выделяют следующие подвиды отношений: субординация; координация; сотрудничество. Каждый подвид обладает определенным психологическим аспектом, влияющий на отношения.

Учитывая психологическое содержание отношений между военнослужащими, их оценивают как соответствующие или не соответствующие, а иногда и противоречащие Уставу Вооруженных Сил. В основном, отношения, которые соответствуют уставу, благоприятно влияют на решение задач, поставленных перед воинским подразделением. Нарушениями воинской дисциплины невыполнение требований устава Вооруженных Сил и проявление неуставных взаимоотношений. Непосредственное влияние на соблюдение уставных правил взаимоотношений военнослужащими влияет уровень сплоченности и боевой слаженности воинского коллектива. Следовательно, каждый офицер должен стремиться, не допускать проявлений неуставных взаимоотношений, анализировать состояние воинской дисциплины в подразделении, совершенствовать воспитательную работу с военнослужащими. Взаимоотношения военнослужащих достаточно полно и четко регламентируются воинскими уставами, но при этом необходимо помнить, что они не могут предвидеть всех нюансов и возможных ситуаций. В любой группе всегда найдутся люди, для которых естественно решать возникшие противоречия исключительно через конфликт. Проводя анализ каждого конкретного случая, это позволяет руководителю накапливать положительный опыт разрешений конфликтов, нарабатывать кейсы оптимальных решений стандартных и нестандартных конфликтных ситуаций, использовать различные методы по их решению.

Дружеские отношения между людьми складываются не в один день. Им предшествует, как правило, товарищеские взаимоотношения. Вновь прибывшее молодое пополнение будет оценивать обстановку морально-психологического настроения в уже установившемся воинском коллективе, и от первой встречи и собеседования с командным составом создастся представление обо всей воинской службе. В начальный период службы у молодых военнослужащих будет формироваться представление о воинском долге, чести и товариществе. На данном этапе командный состав будет играть ключевую роль в сплочении молодого воинского коллектива. Взаимоотношения, сложившиеся в подразделениях, оказывают большое влияние на атмосферу в коллективе на весь период службы. Опытные солдаты, знающие службу, в этот момент способны помочь в становлении молодых воинов, приобщении к уставному порядку.

Взаимоотношения (межличностные отношения) - это внутренняя, социальнопсихологическая сторона взаимодействия между людьми. Это обоюдная готовность людей к определенным типам сотрудничества, которая сопровождается 
эмоциональным переживанием: положительным, индифферентным или отрицательным. В любом коллективе происходит общение, информационное и предметное взаимодействие, в процессе которого реализуются, проявляются и формируются межличностные взаимоотношения. В процессе общения устанавливается эмоциональный контакт и происходит обмен эмоциональными состояниями. Готовность к сотрудничеству может осуществляться как в поведении людей в условиях общения, так и в процессе их совместной деятельности. Именно участие людей и их общение раскрывают характер межличностных отношений: восприятие и понимание людьми друг друга; межличностная привлекательность; взаимовлияние и поведение.

Взаимоотношения между военнослужащими имеют разнообразные формы и виды. По форме построения - официальные и неофициальные; по сфере деятельности (степени взаимного сотрудничества в совместной деятельности) - служебные, общественные и бытовые; по содержанию - положительной и отрицательной направленности; по форме интеграции - объединяющие и разъединяющие; по способам регуляции - субординация, координация, соревнование и сотрудничество; по степени устойчивости (прочности взаимосвязей) - временные и длительные; по степени сопричастности - индифферентные, приятельские и дружеские; по форме проявления истинные, демонстрируемые и приписываемые; по уровню взаимной близости (контактности) взаимодействующих личностей - близкие, дружеские, товарищеские. Характер взаимоотношений в воинском подразделении обусловлен отличительными признаками жизнедеятельности военнослужащих. Особенности воинской службы предполагают проявления сплоченности, взаимопонимания и взаимодействия военнослужащих при выполнении различных задач.

В Российской армии особо почитается войсковое товарищество. По-другому его называют воинским (боевым) братством. Возникновение и развитие войскового товарищества уходит к истокам русской армии. Можно без преувеличения сказать, что история побед российской армии - это еще и история боевого товарищества. Боевое братство - особое понятие, присущее всем поколениям российских воинов, оно не впитывается с молоком матери, а приобретается в тяжелых испытаниях и является замечательной традицией нашей армии. Солдаты делят вместе боль и опасность, лишения и трудности, общую цель и веру. Тяжелый совместный труд - и духовный, и физический, делает людей ближе, чем любые родственные связи.

Товарищеская выручка, взаимопомощь сплачивают воинский коллектив, делают его в разы крепче. В современной жизни достижение победы в бою без них практически невозможно. С ними легче переносятся лишения и тяготы суровой армейской жизни. С честью выполнять свой воинский долг перед Родиной помогает товарищеская поддержка, которая окрыляет солдата и матроса, придает смелость и уверенность.

Результатом грамотного управления военнослужащими является сплоченность. Работа по сплочению воинского коллектива является неотъемлемой составляющей поддержания высокого морально-психологического состояния личного состава, высокой воинской дисциплины и правопорядка, которые напрямую влияют на состояние боевой готовности воинской части и подразделения. При этом считается, что группа удовлетворяет человека, пока нахождение в ней превышают «издержки», больше, чем в какой-то другой группе или вообще вне нее. Наглядным примером поднятия боевого духа воинского коллектива, оптимизма и чувства морального долга перед Отчизной является мероприятие - поднятие государственного флага и исполнение гимна Российской Федерации. Также, сплочению воинского коллектива, укреплению морально-психологического состояния личного состава способствует личная примерность офицеров в исполнении своих служебных обязанностей. И наконец, в процессе длительной совместной службы продолжается упрочение системы ценностно-ориентационного взаимодействия, а деловое и эмоциональное единство 
военнослужащих становится продолжением развития сплоченности воинского коллектива.

Таким образом, межличностные отношения военнослужащих весьма разнообразны и многогранны. Они имеют свою специфику, характеризуются различными механизмами, происходящими в коллективах, в процессе развития сплоченности, возникновения товарищеских взаимоотношений. Успешная подготовка личного состава во многом зависит от умения командира в совершенстве владеть современными формами обучения и методами, а также от умения разрешать межличностные конфликты.

$$
* * *
$$

1. Крупник Е.П., Сизова Т.Б. Теоретические аспекты психологической культуры межличностных взаимодействий. - М., 2001 г.

2. Лазарев В.П., Федотов А.А. Педагогические основы формирования уставных взаимоотношений личного состава полка (корабля). - М., 2007 г.

3. Маклаков А.Г. Психология и педагогика. Военная психология. - СПб., 2004 г. 


\title{
РАЗДЕЛ VI. МЕНЕДЖМЕНТ
}

\author{
Черноусова Т.A. \\ Механизм управления финансово-хозяйственной деятельностью предприятия \\ ФГБОУ ВО Иркутский государственный аграрный университет имени А.А. Ежевского \\ (Россия, Иркутская обл., Иркутский р-н, пос. Молодежный)
}

doi:10.18411/spc-22-11-2018-09

idsp: spub-22-11-2018-09

Любая финансово-хозяйственная деятельность начинается с постановки и ответа на следующие три ключевых вопроса:

1) Сколько нужно активов предприятию, для достижения поставленных цели и задач предприятия, и в каковом соотношении?

2) Какие источники финансирования деятельности предприятия, и в каких пропорциях?

3) Как организовать текущее и перспективное управление финансовой деятельностью, обеспечивающее платежеспособность и финансовую устойчивость предприятия?

Решаются эти вопросы в рамках финансового менеджмента, являющегося одной из ключевых подсистем общей системы управления предприятием.

Организационная структура системы управления финансами предприятия может быть построена различными способами в зависимости от размеров предприятия и вида его деятельности. Главное, что следует отметить в работе финансового менеджера, это то, что она либо составляет часть работы высшего звена управления предприятия, либо связана с предоставлением ему аналитической информации, необходимой и полезной для принятия управленческих решений финансового характера. Вне зависимости от организационной структуры предприятия финансовый менеджер отвечает за анализ финансовых проблем, принятие в некоторых случаях решений или выработку рекомендаций высшему руководству [2, с. 117].

Методы финансового управления многообразны. Основными из них являются: прогнозирование, планирование, налогообложение, страхование, самофинансирование, кредитование, система расчетов, система финансовой помощи, система финансовых санкций, система амортизационных отчислений, система стимулирования, принципы ценообразования, трастовые операции, залоговые операции, факторинг, аренда, лизинг.

Основу информационного обеспечения системы финансового управления составляет любая информация финансового характера:

1) бухгалтерская отчетность;

2) сообщения финансовых органов;

3) информация учреждений банковской системы;

4) информация товарных, фондовых и валютных бирж;

5) прочая информация [3, с. 112].

Техническое обеспечение системы финансового управления является самостоятельным и весьма важным ее элементом. Многие современные системы, основанные на безбумажной технологии, невозможны без применения сетей ЭВМ, персональных компьютеров, функциональных пакетов прикладных программ. 
Функционирование любой системы финансового управления осуществляется в рамках действующего правового и нормативного обеспечения. Сюда относятся: Конституция РФ, Гражданский кодекс РФ Федеральные законы, Трудовой кодекс РФ, указы Президента, постановления правительства, приказы и распоряжения министерств и ведомств, лицензии, уставные документы, нормы, инструкции, методические указания и др.

В условиях рыночной экономики финансовый менеджер становится одной из ключевых фигур на предприятии. Он ответственен за постановку проблем финансового характера, анализ целесообразности использования того или иного способа их решения, а иногда за принятие окончательного решения по выбору наиболее приемлемого варианта действий. Финансовый менеджер, как правило, - ответственный исполнитель принятого решения, он также осуществляет оперативную финансовую деятельность. Главное ее содержание состоит в контроле за денежными потоками.

Приведём признаки успешного финансового управления:

1) выживание предприятия в условиях конкурентной борьбы;

2) снижение риска банкротства и крупных финансовых неудач;

3) лидерство в борьбе с конкурентами;

4) максимизация рыночной стоимости предприятия;

5) рост объемов производства и реализации;

6) максимизация прибыли;

7) минимизация расходов;

8) обеспечение рентабельной деятельности и другое [1, с. 55].

Наиболее распространенным является утверждение, что предприятие должно работать таким образом, чтобы обеспечить максимальный доход ее владельцам.

В финансовом менеджменте весь капитал предприятия можно разделить на две части: собственный и заемный.

Собственный капитал - капитал, безусловным и исключительным собственником которого является собственник (или собственники) предприятия.

К собственному капиталу следует отнести уставный фонд (акционерный капитал), то есть первоначальные и последующие вложения собственных средств собственниками, акционерами и приращение капитала за счет прибыли.

Заемный капитал - капитал, которым предприятие владеет лишь определенное время, по окончании которого капитал должен быть возвращен его собственнику с оплатой за временное владение.

В состав заемного капитала кроме взятых у банка кредитов входят также капитал, привлеченный выпуском ценных бумаг (кроме акций), и арендованные предприятием машины, оборудование, здания [5, с. 32].

Главное в финансовом менеджменте - правильная постановка цели, отвечающая финансовым интересам объекта управления. Эффективность его функционирования во многом зависит от быстроты реакции на изменения условий финансового рынка, финансовой ситуации, финансового состояния объекта управления. Поэтому финансовый менеджмент должен базироваться на знании стандартных приемов управления, на умении быстро и правильно оценивать конкретную финансовую ситуацию, на способности быстро найти хороший, если не единственный, выход из этой ситуации.

Известно, что в сегодняшних условиях для большинства предприятий характерна реактивная форма управления финансами, т.е. принятие управленческих 
решений, как реакции на текущие проблемы. Такая форма управления порождает ряд противоречий между: интересами предприятия и фискальными интересами государства; ценой денег и рентабельностью производства; рентабельностью собственного производства и рентабельностью финансовых рынков; интересами производства и финансовой службы и т.д.

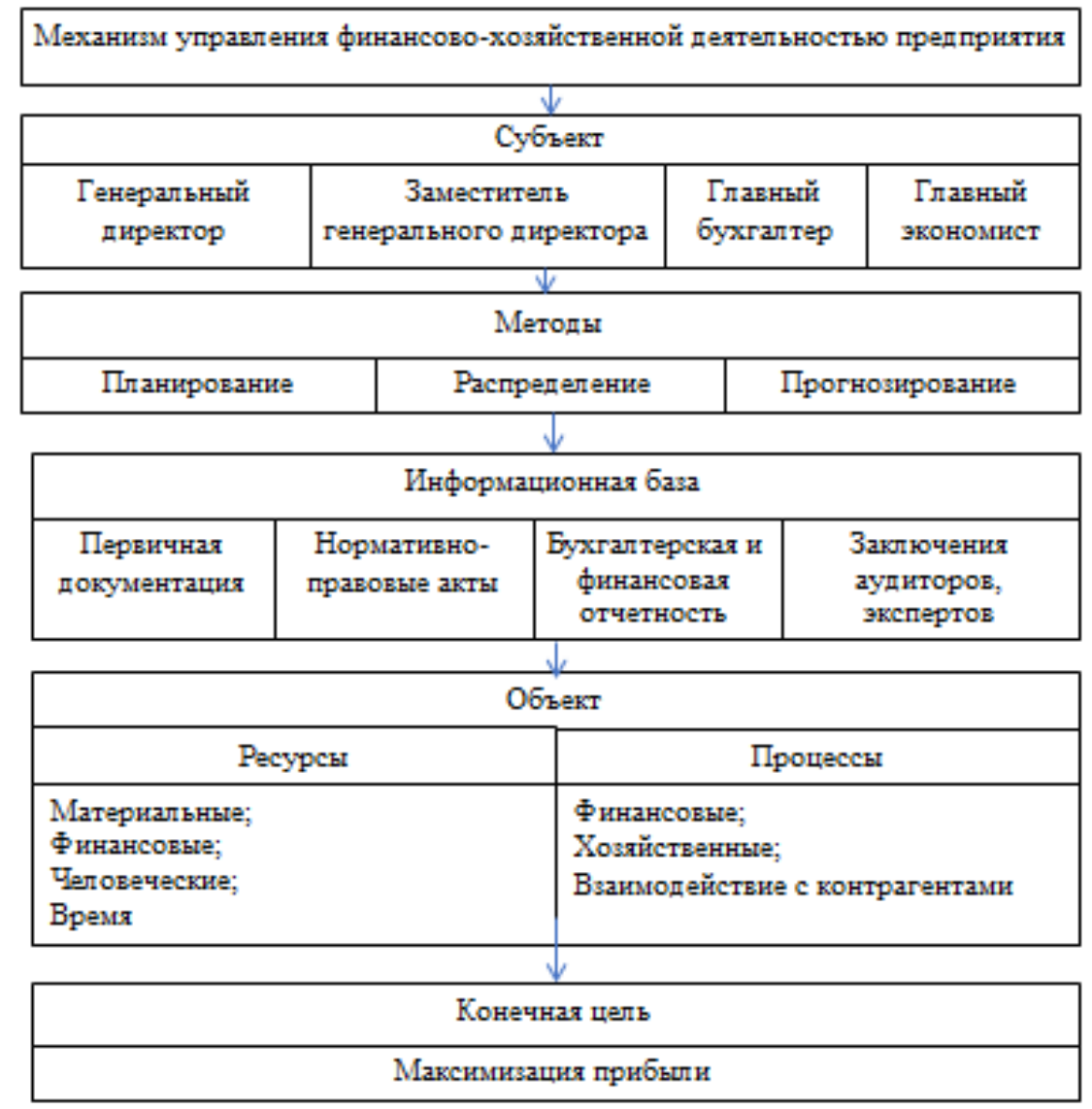

Рисунок 1 - Механизм управления финансово-хозяйственной деятельностью

Таким образом, механизм управления финансово-хозяйственной деятельностью включает в себя: субъект (топ-менеджмент предприятия), объект (ресурсы и процессы предприятия), конечную цель (максимизация прибыли) и методы управления (планирование, распределение, прогнозирование).

$$
* * *
$$

1. Баканов М.И., Шеремет А.Д. Теория экономического анализа / М.И. Баканов, А.Д. Шеремет. - М.: Финансы и статистика. - 2010. - с. 107.

2. Бондарь Н.П., Васюхин О.В., Голубев А.А., Подлесных В.И. Эффективное управление фирмой (современная теория и практика) / Н.П. Бондарь. - СПб.: Бизнес пресса, 2009. - 416с.

3. Иляшевич Д.И., Винокуров Г.М., Мамаева А.И. Методические указания по экономическому анализу для студентов. / Д.И. Иляшевич, Г.М. Винокуров, А.И. Мамаева. - Иркутск: Иркутский ГАУ, 2018. $80 \mathrm{c}$.

4. Монгуш Ю.Д., Ильина Е.А. Оценка финансового результата сельскохозяйственного предприятия / Ю.Д. Монгуш, Е.А. Ильина // Экономика и предпринимательство. - 2018. - 6(95). - С. 1204-1207.

5. Официальный сайт «Национальный плодоовощной союз». [Электронный ресурс]: Режим доступа: https://www.prod.center/news/tag/0/8846-nacionalnyi-plodoovoshchnoi-soyuz 


\title{
РАЗДЕЛ VІІ. СЕЛЬСКОЕ ХОЗЯЙСТВО
}

\author{
Третьякова О..Л. ${ }^{1}$, Зубаиров Р.С. ${ }^{1}$, Пирожков Д.А. ${ }^{2}$ \\ Оценка потенциала продуктивности материнской свинки
}

${ }^{1}$ Донской государственный аграрный университет

(Россия, пос. Персиановский)

${ }^{2}$ Государственный аграрный университет Северного Зауралья

doi:10.18411/spc-22-11-2018-10

(Россия, Тюмень)

idsp: spub-22-11-2018-10

\section{Аннотация}

Объект исследований - материнские свинки ЗАО «Племзавода-Юбилейный» Тюменской области. Цель работы - проанализировать данные роста и развития чистопородных и гибридных свинок, оценить показатели продуктивности. При анализе данных использовались следующие методы: зоотехнический, биометрический, статистический. Измерения свинок проводили при достижении ими живой массы 100 кг, учитывались и обрабатывались следующие показателями: возрастом достижения живой массы 100 кг, среднесуточным приростом, длиной туловища, толщиной шпика, глубиной мышцы, выходом мяса. В 2015 году проверили 3923 свинки, в 2016 году 5792 головы, в 2017 году - 5202 головы. Продуктивность свиноматок оценивалась по следующим показателям: количество опоросов, количество рождённых поросят, количество живых поросят, вес поросёнка при рождении, молочность, масса гнезда к отъему, масса одной головы к отъёму.

Ключевые слова: гибридные, материнские, свинки, опоросы, количество поросят, рождено, молочность, масса при рождении, масса при отъёме, показатели роста, развитие, длина туловища, глубина мышцы, выход мяса, толщина шпика.

\section{Abstract}

Object of research - maternal pigs of JSC "Plemzavoda-Yubileyny" Tyumen region. The aim of the work is to analyze the data of growth and development of purebred and hybrid pigs, to assess productivity. The following methods were used in data analysis: zootechnical, biometric, statistical. Measurements of pigs were carried out when they reached the live weight of $100 \mathrm{~kg}$, the following parameters were taken into account and processed: age of reaching the live weight of $100 \mathrm{~kg}$, average daily gain, body length, fat thickness, muscle depth, meat yield. In 2015, 3923 pigs were checked, in 2016 - 5792 heads, in $2017-5202$ heads. The productivity of sows was estimated by the following indicators: the number of farrowing, the number of born pigs, the number of live pigs, the weight of the pig at birth, milk, the mass of the nest to weaning, the mass of one head to weaning.

Введение. Мировые генетические компании мира ведут селекционно-племенную работу в материнских линиях на продуктивные качества (плодовитость, общее количество рождённых поросят, жизнестойкость поросят), а также на материнские качества (молочность и т.д.). Все специализированные линии свиней, чистопородные и гибридные линии, полученные путём скрещивания разных генетических типов, являются селекционным достижением. [1,2,3] 
В ЗАО «Племзавод-Юбилейный» Тюменской области внедрена система гибридизации, основанная на скрещивании отселекционированных чистопородных линий свиней и гибридных линий: материнских (ЛхКБ), отцовских (ПхКБ), (ДхП), (КБхП).

Селекция в материнских линиях ведётся на крепость конституции, количество функциональных сосков, многоплодие, материнские качества, показатели роста и развития, постного мяса. Для оценки животных разработаны селекционные индексы (индекс ремонтного молодняка, индекс первого осеменения, индекс товарной массы, IBV, Блап). Каждый из индексов позволяет провести оценку в различные возрастные периоды по различным признакам. [4,5]

Целью исследований является анализ продуктивных (воспроизводительных, откормочных и мясных качеств) чистопородных и гибридных материнских свиноматок для получения большего количества товарных гибридов.

Материал и методика исследований. При анализе данных использовались следующие методы: зоотехнический, биометрический, статистический. Измерения свинок проводили при достижении ими живой массы 100 кг, учитывались и обрабатывались следующие показателями: возрастом достижения живой массы 100 кг, среднесуточным приростом, длиной туловища, толщиной шпика, глубиной мышцы, выходом мяса. В 2015 году проверили 3923 свинки, в 2016 году - 5792 головы, в 2017 году - 5202 головы. Продуктивность свиноматок оценивалась по следующим показателям: количество опоросов, количество рождённых поросят, количество живых поросят, вес поросёнка при рождении, молочность, масса гнезда к отъему, масса одной головы к отъёму.

Результаты исследований. Анализ роста и развития свинок проводили при достижении живой массы 100 кг. Показатели измерения приведены в таблице 1.

Таблица 1

Прижсизненная оиенка гибридных свинок (ЛхКБ).

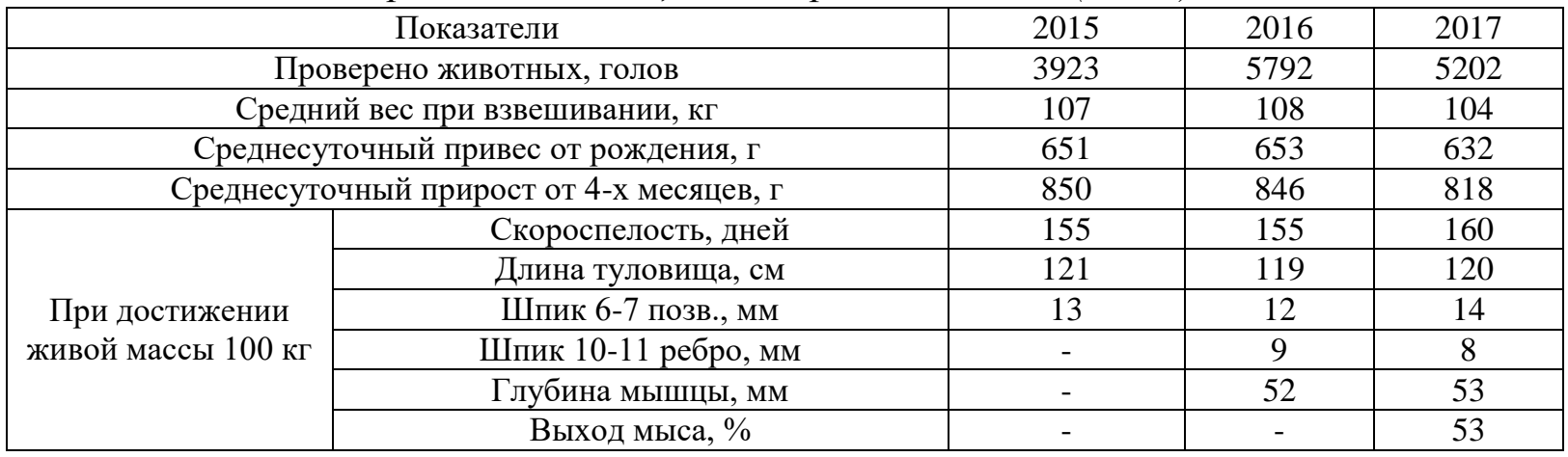

В 2017 году по результатам измерений гибридных свинок (ЛхКБ), отмечается снижение живой массы на 3 кг по сравнению с 2015 г. и на 4 кг по сравнению с 2016 г ,среднесуточного прироста от рождения на 19 г и на 21 г, толщины шпика на уровне 1011 ребра на 1 мм соответственно. Наблюдается увеличение возраста достижения 100 кг на 5 дней, длины туловища на 1 см, глубины мышцы на 1 мм по сравнению с 2016 г.

Для сравнительного анализа показателей роста и развития проведена оценка роста и развития чистопородных свинок (табл.2). 
Таблица 2

Прижизненная оценка чистопородных свинок

\begin{tabular}{|c|c|c|c|c|}
\hline & Показатели & Ландрас & КБ* & Пьетрен \\
\hline \multirow{4}{*}{$\begin{array}{c}\text { При достижении } \\
\text { живой массы 100 кг }\end{array}$} & Скороспелость, дней & 155 & 171 & 166 \\
\cline { 2 - 5 } & Длина туловища, см & 119 & 116,4 & 117 \\
\cline { 2 - 5 } & Шпик 6-7 позв., мм & 8 & 13 & 8 \\
\cline { 2 - 5 } & Среднесуточный прирост, г & 847 & 774 & 762 \\
\cline { 2 - 5 } & Глубина мышцы, мм & 2,8 & 53 & 59 \\
\hline
\end{tabular}

Примечание: * КБ - крупная белая порода свиней.

Отмечено, что лучшую скороспелость показали свинки породы ландрас, которые достигли живой массы 100 кг за 155 дней. Свинки породы пьетрен набрали массу 100 кг за 166 дней. Наибольшее количество дней (171) для достижения массы 100 кг потребовалось свинкам породы крупная белая.

Свинки породы ландрас характеризовались высоким среднесуточным приростом 847 г, что на 73 г больше, чем у свинок крупной белой породы, и на 85 г по сравнению с породой пьетрен.

Сравнительный анализ чистопородных и гибридных свинок по показателям: скороспелости, длине туловища приведен на рисунках 1,2.

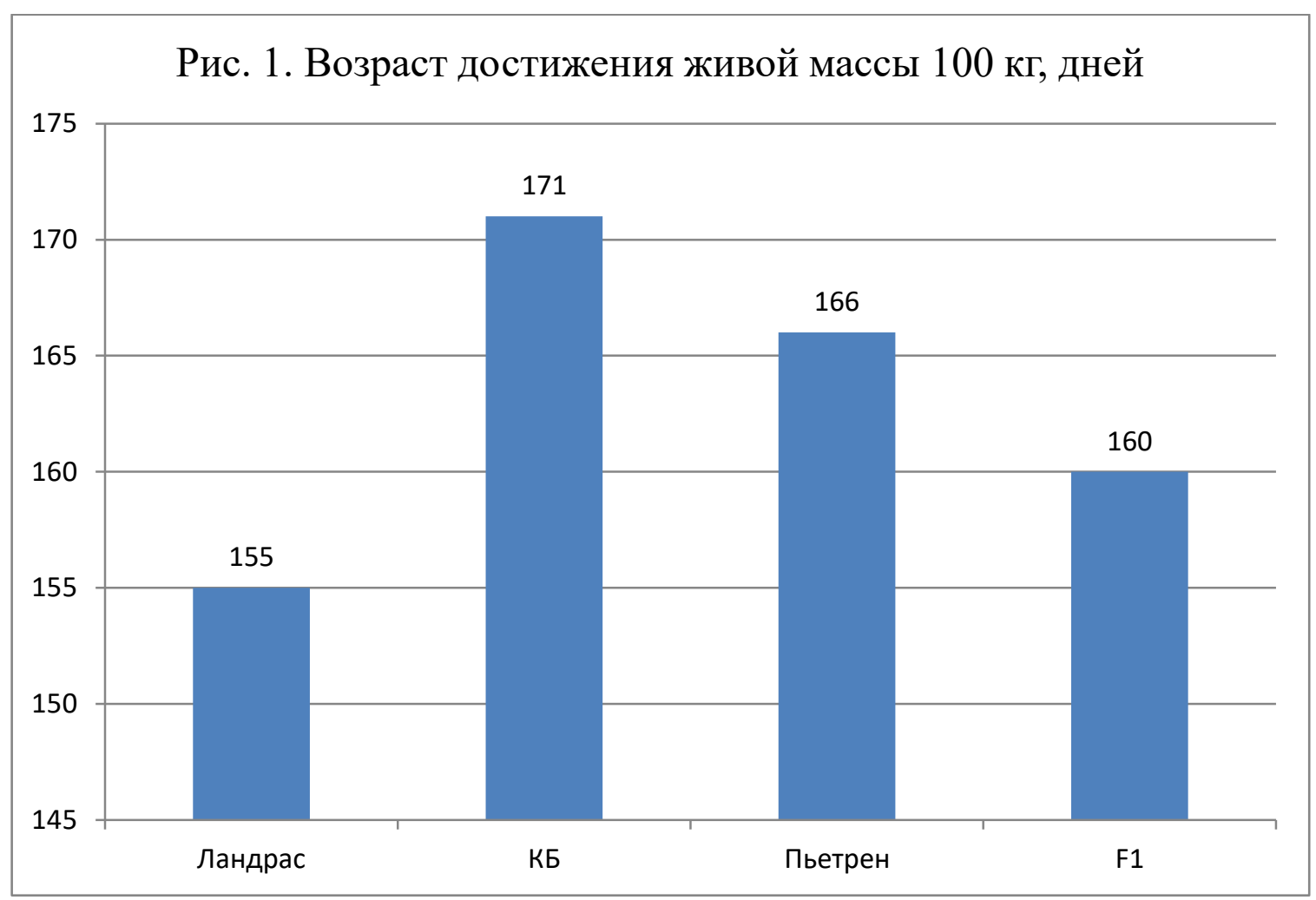

Отмечено, что возраст достижения живой массы 100 кг у гибридных свинок F1 составил 160 дней, что выше на 5 дней, чем у чистопородных свинок породы ландрас и ниже на 6 дней, чем у чистопородных свинок породы пьетрен, на 11 дней ниже, чем у чистопородных свинок крупной белой породы. 


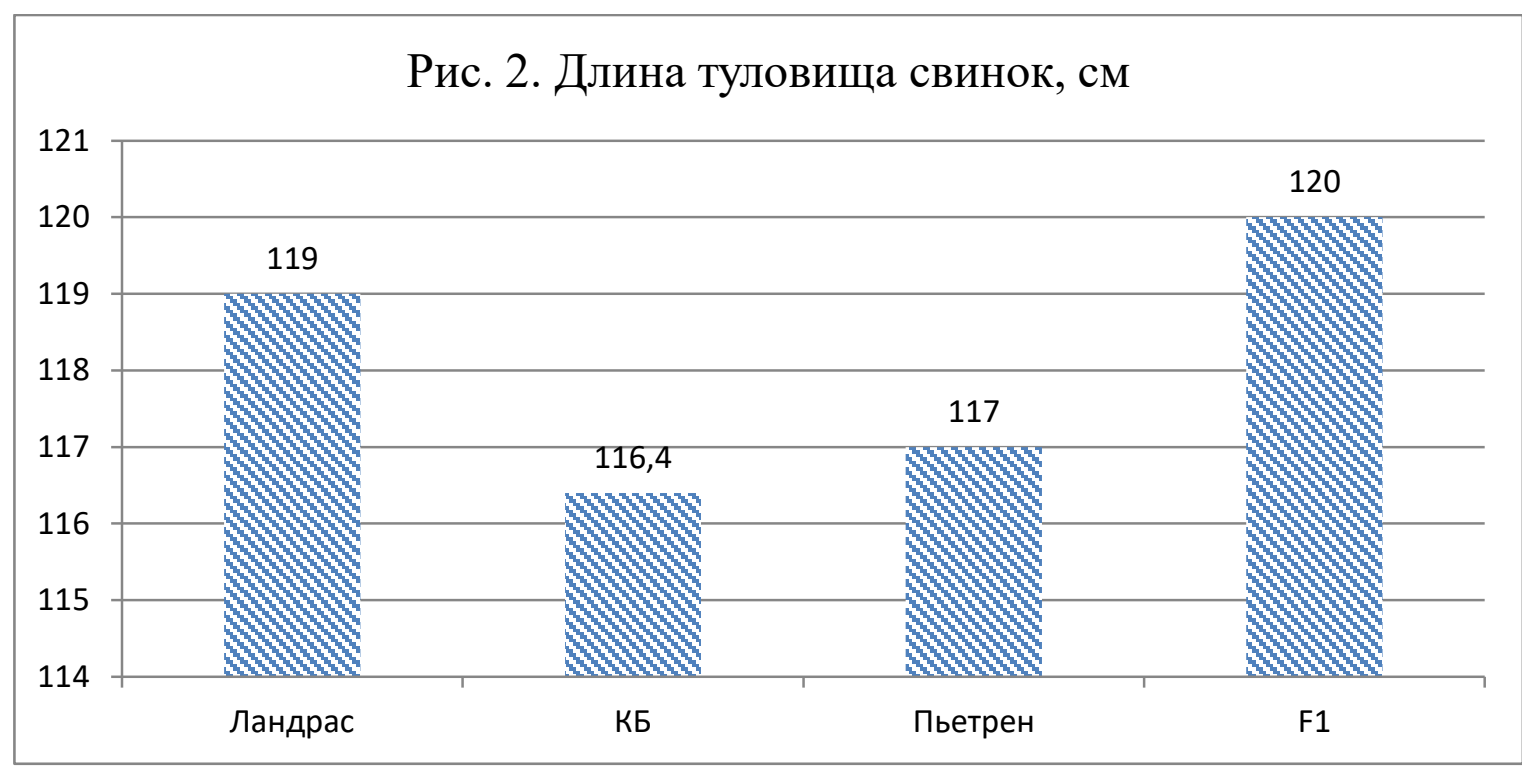

График промеров длины туловища показывает, что у гибридных свинок она составила $120 \mathrm{~cm}$, что выше на $1 \mathrm{~cm}$, чем у чистопородных свинок породы ландрас, на 3 см, чем у чистопородных свинок породы пьетрен, и на 3,6 cм, чем у чистопородных свинок крупной белой породы.

В результате сравнительного анализа роста и развития свинок установлено, что гибридные свинки имеют показатели превосходящие показатели чистопородных свинок.

Анализ продуктивности свиноматок F1 проведен по базе данных АВСC (10.11.2017) исследовались данные продуктивности свиноматок 2014 года рождения, 2015 года рождения, 2016 года рождения. Проведена выборка 5053 гибридных свиноматок F1 (2014, 2015, 2016 года рождения), проанализировано 16507 осеменений, получено 12038 опоросов. В результате процент оплодотворяемости составил 97,1\%, мертворожденных - 4,88\%, отдых свиноматок - 7 дней. Показатели продуктивности всех гибридных свиноматок F1 по опоросам приведены в табл.3.

Таблица 3

Показатели продуктивности всех гибридных свиноматок F1.

\begin{tabular}{|c|c|c|c|c|c|c|c|c|}
\hline \multicolumn{2}{|c|}{ родилось } & \multirow[b]{2}{*}{$\begin{array}{l}\text { масса } \\
1 \text { гол. }\end{array}$} & \multicolumn{2}{|c|}{ в 21 день } & \multicolumn{3}{|c|}{ в отъём } & \multirow{2}{*}{$\begin{array}{c}\text { средне- } \\
\text { суточный } \\
\text { прирост }\end{array}$} \\
\hline всех & живых & & кол-во & $\begin{array}{c}\text { масса } \\
\text { гнезда }\end{array}$ & $\begin{array}{c}\text { кол- } \\
\text { во }\end{array}$ & $\begin{array}{c}\text { масса } \\
\text { гнезда }\end{array}$ & $\begin{array}{l}\text { масса } \\
1 \text { гол. }\end{array}$ & \\
\hline \multicolumn{9}{|c|}{ все опоросы } \\
\hline 13,3 & 12,7 & 1,25 & 11,5 & 69,2 & 11,4 & 122,2 & 3,5 & 167,5 \\
\hline \multicolumn{9}{|c|}{ все нормальные опоросы } \\
\hline 13,2 & 12,5 & 1,21 & 11,5 & 69,2 & 11,5 & 222,8 & 7,1 & 305,0 \\
\hline
\end{tabular}

От 3414 свиноматок F1 (ЛхКБ) получено 5311 нормальных опоросов, в среднем рождено 13,2 головы, из них 12,5 живых, вес при рождении 1 головы 1,21 кг, количество поросят в 21 день 11,5 гол., молочность 69,2 кг, количество поросят к отъёму - 11,5 гол., масса гнезда к отъёму 82,3 кг, среднесуточный прирост поросят от рождения до 30 дней - 305 г.

Выводы. Оценивая результаты роста и развития материнской гибридной свинки следует отметить эффект превосходства по показателям скороспелости, длины туловища у свинок F1 по сравнению с чистопородными. При анализе продуктивности гибридных свиноматок выявилось повышение количества рожденных и живых поросят 
в зависимости от порядкового номера опороса. Также с возрастом и увеличением порядкового номера опороса увеличивается молочность и масса одной головы и гнезда при отъёме. Гибридные свиноматки имеют высокий потенциал по количеству рождённых и живых поросят, максимальное количество составило 22 головы на опорос. При оценке, товарных гибридов отмечается снижение возраста достижения живой массы 100 кг, затрат корма, толщины шпика. Увеличивается глубина мышцы. Так у четырёхпородных гибридов глубина мышцы 58 мм, у трёхпородных (ЛхКБ)хД 64 мм, у трёхпородных (ЛхКБ)хП - 63 мм. Выход мяса в туши по гибридам составил: у четырёхпородных гибридов - 53\%, у трёхпородных (ЛхКБ)хД - 55\%, у трёхпородных (ЛхКБ)хП - 57\%. Увеличилось количество туш имеющих категорию Е.

$$
\text { *** }
$$

1. Михайлов Н.В., Святогоров Н.А., Третьякова О.Л., Святогорова А.Е. Селекционные модели для оценки откормочной и мясной продуктивности в свиноводстве. В сборнике: Актуальные проблемы производства свинины в РФ. Материалы XXIII заседания межвузовского координационного совета по свиноводству и международной научно-практической конференции. Пос. Персиановский, 2013. C.78-82.

2. Третьякова О.Л., Острикова Э.Е., Мамонтов С.Н., Фетисов В.В. Селекция - залог успеха. Ветеринарная патология. 2014. №3-4 (49-50). С.97-103.

3. Третьякова О.Л., Клименко А.И., Федин Г.И. Программы селекции свиней. Вестник Калмыцкого университета. 2014. №1 (21). С. 22-26.

4. Третьякова О.Л., Федин Г.И., Гетманцева Л.В., Приступа В.Н., Г.М. Бажов Разработка и внедрение эффективных методов и программ селекции свиней. Аграрный вестник Урала. 2013. №9. С.16-20.

5. Третьякова О.Л., Костин М.Ю., Сирота И.В. Откормочные и мясные качества чистопородных и гибридных подсвинков В сборнике: Селекция сельскохозяйственных животных и технология производства продукции животноводства. Материалы международной научно-практической конференции. пос. Персиановский, 2016. С.203-207. 


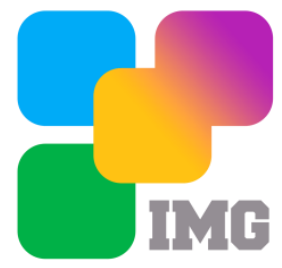

Научное издание

Научный диалог:

Молодой ученый

Сборник научных трудов, по материалам

XXI международной научно-практической конференции

22 ноября 2018 г.

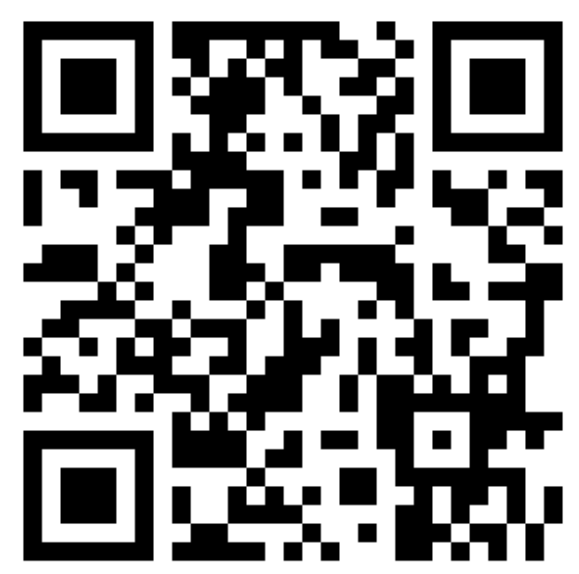

SPLN 001-000001-0358-YS

Подписано в печать 05.12.2018. Тираж 400 экз.

Формат.60х841/16. Объем уч.-изд. л 2,3

Бумага офсетная. Печать оперативная.

Отпечатано в типографии Международной Объединеной Академии Наук

Главный редактор: Иванов Владислав Вячеславович 